\title{
The Large-Scale Aspects of the Characteristic Features of the Baiu Front*
}

\author{
With Special Emphasis on the Relation Among the Ageo- \\ strophic Low-level Jet Stream, Moist Tongue, Convective \\ Warming, Convergence Zone within Baiu Front and Heavy Rainfall-
}

, by

Takako Akiyama

Meteorological Research Institute, Tokyo

(Received February 28, 1973)

\begin{abstract}
The large-scale aspects of the Baiu Front, heavy rainfall and associated phenomena are analyzed over the Far East during the 40day period from June 16 to July 25,1968 , mainly by using 5 -day mean fields of various meteorological elements.

The Baiu Front over the Far East forms a belt-shaped zone of maximum cloudiness, which lies east and west along the northern boundary of the monsoon or tropical airmass. This cloud zone coincides well with the zone of maximum rainfall amount. Heavy rainfalls there indicate successive convective activities. Owing to the convective transport of moisture, sensible heat and release of latent heat, a midtropospheric warm belt and a deep moist layer are formed within the Baiu Front.

The most notable feature of the mean Baiu Front is the appearance of the core of the super-geostrophic strong wind in the lower troposphere during the heavy rainfall periods. It is suggested that the low-level jet is intensified by the vertical mixing of horizontal momentum due to active convections there.

Medium-scale disturbances develop successively in the Baiu frontal zone which provides favorable conditions for their generation as inferred from the small Richardson Number.

The results of water-vapor budget in the vicinity of the Baiu Front reveal that a large amount of water-vapor convergence within the frontal zone is mainly by northeastward flow along the northwestern rim of the Northern Pacific Subtropical anticyclone. It is also concluded that the evaporation from the western Pacific is one of the important vapor sources which maintain intense rainfall within the Baiu Front.
\end{abstract}

* This report has been made as a part of the work of the Heavy Rainstorms Research Project of Japan. 


\section{Contents}

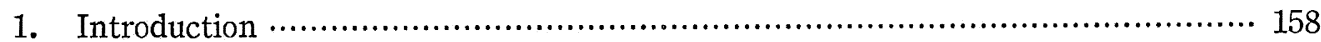

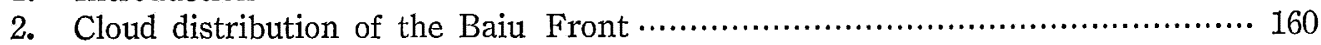

3. Rainfall amount in the Baiu Front …………………………………... 165

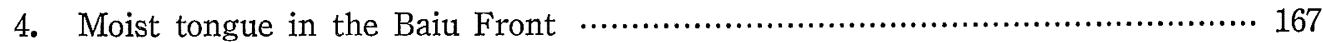

5. Low-level jet stream in the Baiu Front …………………………………... 169

6. The stratification of the Baiu Front and development of medium-scale

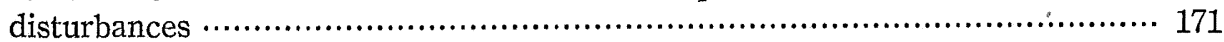

7. Influence of convective warming on thermal and wind fields in the upper troposphere over the Baiu Front ……………...................................... 173

8. Water vapor budget in the vicinity of the Baiu Front ……………............ 175

8.1 Horizontal water vapor flux in the vicinity of the Baiu Front ……........ 176

8.2 Water vapor supply from the sea surface ………………………...... 178

8.3 Water vapor budget of the Baiu Front ………….............................. 180

9. Intensification of the Baiu Front along the northwestern rim of the Northern Pacific Subtropical anticyclone ……………............................. 184

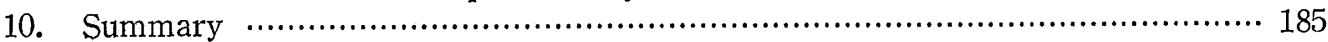

\section{Introduction}

The rainy season in East Asia occurs with the onset of the summer monsoon. Various aspects of the summer monsoon and the associated rainfall have been studied climatologically and synoptically by many authors. Their results are summarized in an extensive review paper by RAMAGE (1971).

The early summer rainy season is one of the conspicuous phenomena in the Far East (i.e., China and Japan*). The belt-shaped maximum rainfall zone extending from west to east is located over southern China in late spring. This maximum rainfall zone gradually advances northwards over the Japan Islands and brings heavy rainfalls in Japan usually in the end of June and the beginning of July.

Many meteorologists had an interest in the relations among the wind systems, moisture transport and rainfall in the Far East. By extensive analyses of the largescale wind systems, air-masses distribution and the water budget in the summer season over the Far East, Murakami (1959) pointed out that the moisture flow associated by the Indian westerlies plays an important role in shaping a rainfall zone in the early stage of the rainy season. In the last stage of the season, however, he mentioned that the moisture flow from the south Pacific becomes significant. SAITo (1966) also examined the large-scale features of the summer monsoon for the summer of 1964. He showed that the distinct moist zone is usually found north of the SW or SE monsoon rather than in the monsoon itself. In the climatological study on the large-scale rainfall distribution during the summer monsoon season, Yoshino (1966) described that the distinct rainfall belt lies over the Far East and gradually moves northwards with the advance of the rainy season. In the climatological analysis of the general

\footnotetext{
* The rain in this season is called Mai-yu and Baiu in China and Japan respectively.
} 
circulation of the monsoon season, KURASHIMA (1968) says that there are two stages in the development of the summer monsoon and that the tropical and subtropical monsoon prevails in the second stage, during which heavy rainfalls occur over the Far East. By using satellite cloud pictures, AsAKuRA (1971 b) analyzed the large-scale cloud distribution. He found that the zone of the maximum cloudiness coincides with the moist zone. He also pointed out in his paper $(1971 \mathrm{a}) *$ on the water balance over monsoon Asia, that the source of water vapor is found over the oceans covered by the subtropical anticyclone.

Next, we will see the features of rainfall over the Japan Islands in more detail. A family of small cyclones frequently develops along the Baiu Front and sometimes causes intense rainfalls. The rainfall amount of a few or several hundred mm per day is not unusual in southwestern Japan. This kind of severe situation would be difficult to understand from the results of climatological or large-scale analyses mentioned above. The Severe Rainstorms Research Project of Japan Meteorological Agency has carried out the observational experiment in western Japan since 1968 to clarify the mechanism of this heavy rainfall in the Baiu Front. By analyzing data obtained during the 4-day period of the First Experiment in July of 1968 and the 7-day period of the Second Experiment in July 1969, Matsumoto, Yoshizumi and Takeuchi (1970) and MATSUmoto, NiNomiYa and Yoshizumi (1971) revealed many characteristic features of the Baiu Front associated with heavy rainfalls. Their results will be summarized very briefly in the following paragraph. The Baiu Front is characterized by the beltshaped zone of maximum cloudiness and rainfall amount along the northern boundary of the monsoon or tropical air-mass. The mid-tropospheric warm belt over the deep moist layer is found along the Baiu Front. The stratification within the frontal zone is almost neutral (i.e., near the wet-adiabatic lapse rate). Another important feature is the core of the super-geostrophic strong wind in the lower troposphere (i.e., the low-level jet stream) along the front. The stratification and the low-level strong wind suggest the vertical mixing of heat energy and momentum due to the active convections there. They also pointed out that medium-scale disturbances with wave-lengths of about $1,000 \mathrm{~km}$ developed to the north of the axis of the low-level jet. By analyzing the water vapor budget, they showed that the convergence of water vapor flux is mainly caused by the northward transport of vapor into the frontal zone due to the southerly monsoon.

Although many important features of the Baiu Front were revealed by them as mentioned above, further studies will be necessary to know the behaviors of the Baiu Front during the whole Baiu season, since their analyses were concerned only with short periods and relatively small areas near the Japan Islands.

In this report, we will analyze the large-scale synoptic aspects of the Baiu Front and associated phenomena over the Far East during the 40-day period from June 16 to July 25, 1968. One of the objects of the analysis is to examine whether the features revealed by МАтSUмото et al. (1970, 1971) are observed generally throughout the whole Baiu season or not. We also intend to clarify the characteristic features of the Baiu Front in the Far East and the details of its time variation through the

* The data sources used for the water budget by SAIto (1966) and ASAKURA (1971 a,b) are the data obtained by the automatic data-processing and objective analysis systems of the Electronic Computation Center of Japan Meteorological Agency. The grid interval for the former and latter analysis is $305 \mathrm{~km}$ and $381 \mathrm{~km}$ respectively. 


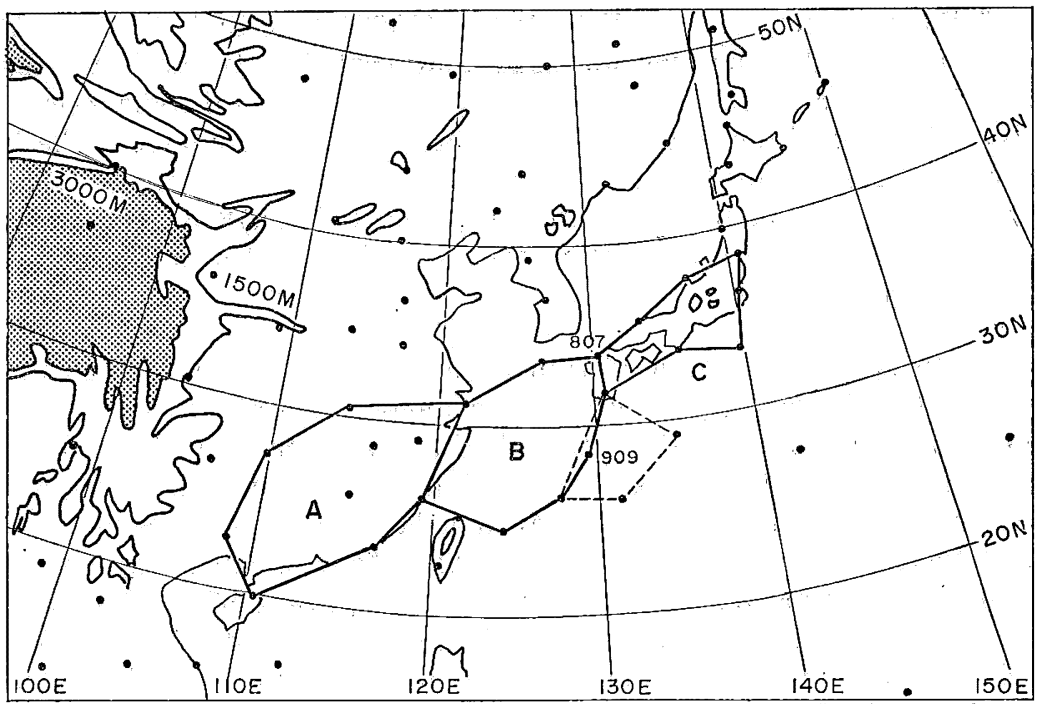

Fig. 1. Observation network used for present analysis. Black points show aerological observation stations. Polygonal regions enclosed by solid lines are used for water vapor budget calculation. The quadrangle indicated by a dashed line is used for calculation of geostrophic wind.

whole Baiu season.

One of the sources of the data materials used in the present study is the aerological data at the surface, 850,700,500,400,300 and 200-mb* surfaces observed by the aerological stations presented in Fig. 1. Since we have an interest in the actually observed values rather than the smoothly interpolated field, we will analyze the observed values at each station. In order to show the orographic features of the analyzed area, the contours for the 1500 and 3000 meter altitude are presented in Fig. 1.

Another source is the ESSA-5 1/4 northern hemispherical digitized mosaicked cloud pictures.

We will describe the large-scale aspects of the Baiu Front mainly by analyzing the 5-day mean field during the 40 -day period mentioned above,

\section{Cloud distribution of the Baiu Front}

At the beginning of this analysis, let us examine the large-scale cloud aspects of the Baiu Front on satellite pictures. Three sheets of cloud pictures are shown in Fig. 2 as examples. These are ESSA-5 $1 / 4$ northern hemisphere cloud pictures for June 20, July 11 and 20, 1968. They represent cloud features at the middle and the late Baiu season and the post-Baiu season over southwest Japan respectively. It is seen on Fig. 2 that there is a huge cloud mass over the North Pacific, from which a belt-shaped cloud extends to the China Continent. It is also seen that a wide cloudless region spreads over the Pacific Ocean far to the south of the Japan Islands. They correspond

* The data above $400 \mathrm{mb}$ are missing at some stations on the continent. 


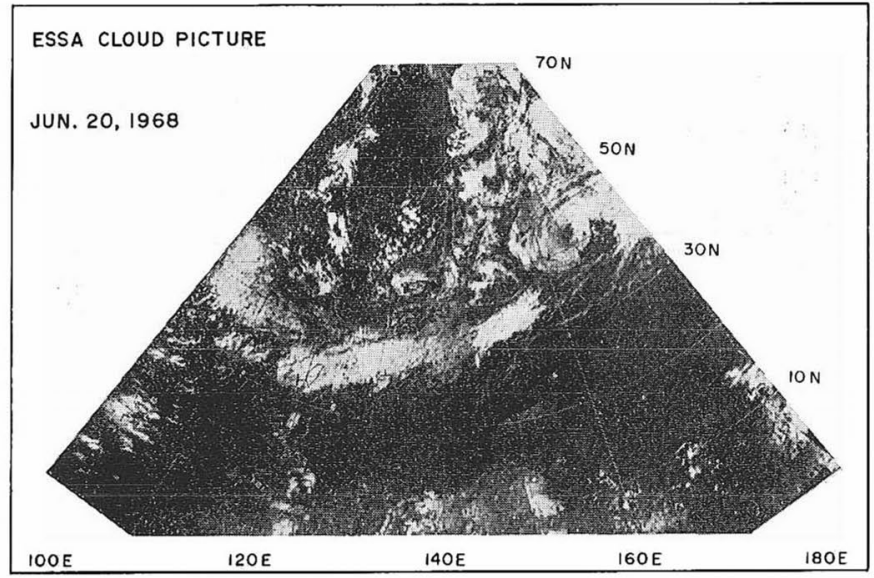

Fig. 2a. A sample of ESSA 1/4 northern hemisphere digitized satellite pictures for June 20, 1968 .

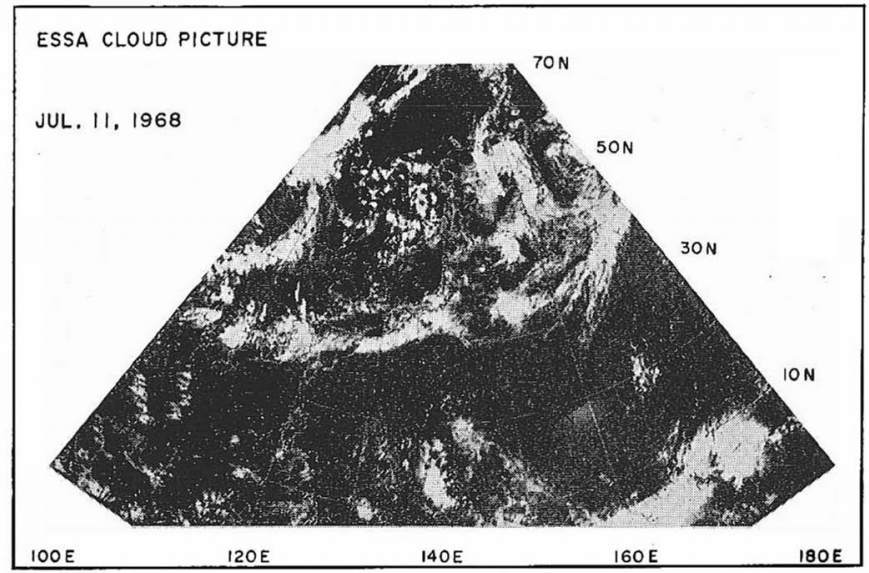

Fig. 2b. Same as Fig. 2a, but for July 11.

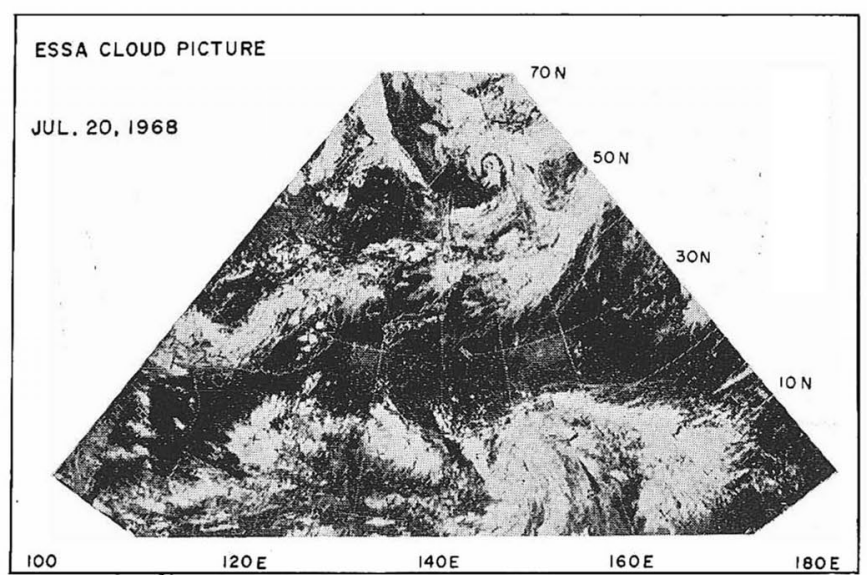

Fig. 2c. Same as Fig. 2a, but for July 20. 

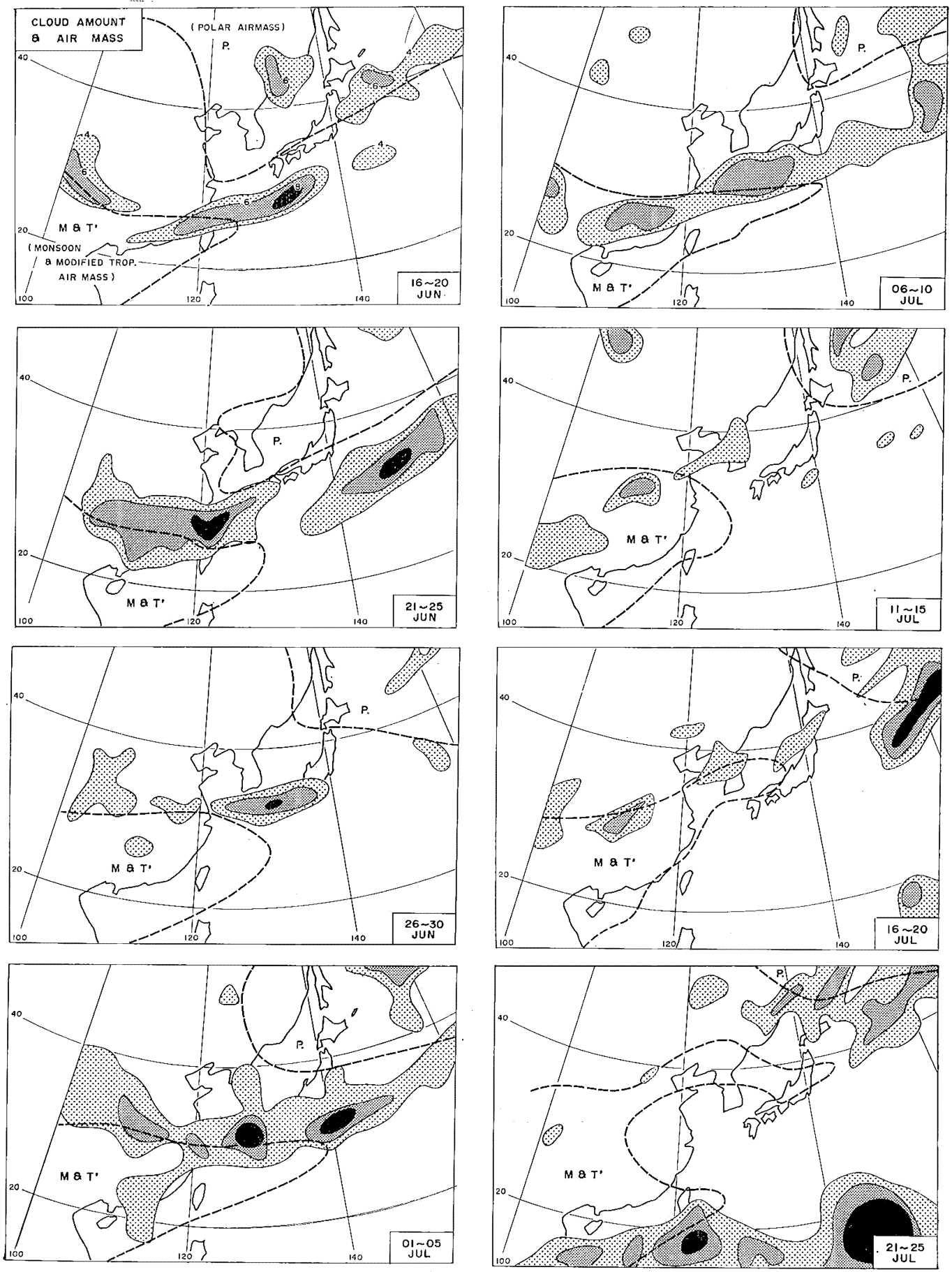

Fig. 3. 5-day mean cloudiness charts during the period from June 16 to July 25, 1968. The areas of mean cloudiness exceeding $4 / 10,6 / 10$ and $8 / 10$ are shown by stipples, dense stipples and blackened areas respectively. The area bounded by thick dashed lines indicates the regions of monsoon $(M)$ and modified tropical $\left(T^{\prime}\right)$ airmass and polar $(P)$ airmass. 
to the Aleutian low, the Baiu Front and the Northern Pacific Subtropical anticyclone respectively. Tracing this belt-shaped cloud zone throughout the time sequences of the pictures for 40 days, we can clearly recognize the seasonal shift of the Baiu Front, i.e., northward progress with the advance of the season. It is also found that the row of a few cloud clusters forms a frontal belt together with the large-scale cloud mass accompanied with cyclone waves. NinomiYA and AxiYAma $(1971,1972)$ pointed out that these cloud clusters, whose wave-length is about $1,000 \mathrm{~km}$, are associated with medium-scale disturbances embedded in the front.

Since we can find the belt-shaped cloud zone even on the daily pictures and the Baiu Front is a stationary front, it would be seen more clearly on mean cloudiness charts. By analyzing 5-day mean cloud distribution over the Far East in the Baiu season of 1969 by using the satellite APT mosaicked pictures, ASAKURA (1971 b) has already shown that a pronounced cloud belt extends from the Aleutian Islands to south China during the Baiu season. The resolution of the digitized composite cloud picture used in the present study, however, is much higher than that of the APT picture. Therefore the results of the mean cloudiness analyses of this study are more accurate than Asakura's results.

In order to obtain the 5-day mean cloudiness over the period under consideration, we determined the cloud amount for every two degrees longitude and latitude square from daily cloud pictures, and then averaged these values for each 5-day period. The time variation of mean cloudiness thus obtained is presented in Fig. 3. In the figure, areas of mean cloudiness exceeding $4 / 10,6 / 10$ and $8 / 10$ are shown by stipples, dark stipples and blacked area respectively. Throughout the Baiu season, the belt-shaped heavy cloud zone is recognized clearly extending from east to west over East Asia. This zone gradually shifts northwards in the Baiu season, but rapidly at the end of the season. After the cloud zone has passed over the Japan Islands, the cloudiness decreases and then the belt-shaped cloud zone disappears. To the south of the maximum cloudiness zone, a vast cloudless area spreads over the ocean covered by the Northern Pacific subtropical anticyclone. This cloud zone would be very stationary as supposed from the mean cloud amount exceeding $40 \%$. It is noticed, moreover, that the most heavy cloudiness area is found in the vicinity of the Japan Islands throughout the Baiu season. This suggests that the Baiu Front is intensified there.

Next, let us discuss the air-mass distribution over East Asia in the Baiu season. Air-mass analysis over the Far East in the summer monsoon season was made by many authors, e.g., Murakami (1959), SAITo (1966). In the present study, air-

Table 1. Classification of airmass.

\begin{tabular}{ll|rr|rr}
\hline \hline Designation & \multicolumn{1}{c|}{ air mass } & \multicolumn{2}{|c|}{$850 \mathrm{mb}$} & \multicolumn{2}{c}{$700 \mathrm{mb}$} \\
& & $\begin{array}{c}q \\
(\mathrm{~g} / \mathrm{kg})\end{array}$ & $\theta_{e}$ & $\theta_{e}$ \\
\hline$M$ & $\geq 12$ & $\geq 340$ & $\geq 8$ & $\geq 340$ \\
$T^{\prime}$ & (monsoon) & $\geq 12$ & $\geq 340$ & $\geq 6$ & $\geq 330$ \\
& (modified tropical) & $\geq 10$ & $\geq 330$ & $\geq 6$ & $\geq 330$ \\
$P$ & (tropical) & & $320 \geq$ & & \\
\hline
\end{tabular}

$q:$ mixing ratio, $\theta_{e}:$ equivalent potential temperature 

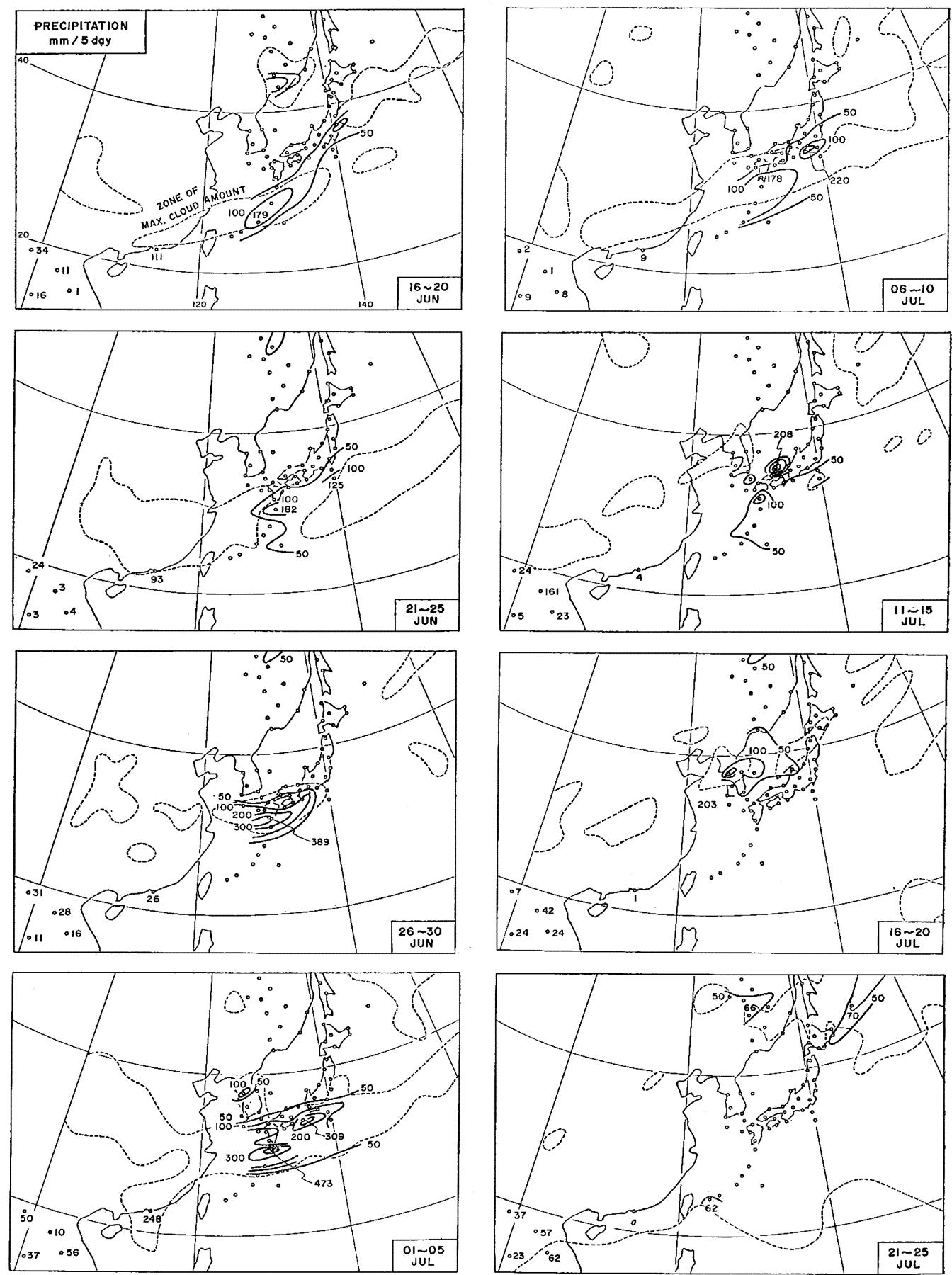

Fig. 4. Distribution of 5-day rainfall amount during the period from June 16 to July 25,1968 (unit $\mathrm{mm} / 5$ day). Small circles show the raingauge stations used for rainfall analysis. The area bounded by dashed lines indicates the zone of maximum cloudiness exceeding 4/10. 
mass analysis was made by applying Saito's criterion for air-mass identification (see Table 1) and the result is also shown in Fig. 3. In the figure, the monsoon, modified tropical and polar airmasses are denoted by $M, T^{\prime}$ and $P$ respectively. $M$ and $T^{\prime}$ air-masses are characterized by high temperature and high humidity. Their area spreads over from the south China Continent to Formosa, protruding toward the Japan Islands in the middle and late stage of the Baiu season. The region of the Northern Pacific subtropical anticyclone is covered by the tropical airmass. The $P$ airmass spreading around the North Pacific Ocean protrudes southwest to the Japan Sea at the beginning of the Baiu season. Its southern boundary, however, retreats northwards with the progress of the season. The belt-shaped zone of maximum cloudiness extends along the northern boundary of the $M, T^{\prime}$ air-mass throughout the Baiu season. It may be said that the cloud zone corresponds to the Baiu frontal zone, although the gradient of temperature is weak within the cloud zone as shown in the latter sections below.

\section{Rainfall amount in the Baiu Front}

In the previous section, it was stated that a zone of heavy cloudiness, where mean cloud amount exceeds 40 per cent, is found over the Far East and that it coincides with the frontal zone. It may be expected that a considerable amount of rain should fall within this cloud zone.

Now let us examine rainfall distribution in relation to the belt-shaped cloud zone. Fig. 4 is the time series of the maps of 5-day period rainfall distribution. Small circles indicate the raingauge stations used for this analysis. At the present time, it is difficult to prepare maps of rainfall distribution over the whole area under consideration, but fine networks in Japan, Korea and USSR are available for examining the features of rainfall area and the relation between rainfall amount and cloudiness. The areas of cloud amounts exceeding 40 per cent, whose boundaries are shown by dashed lines in Fig. 4, coincide well with the heavy rainfall areas where the rainfall amount exceeds $50 \mathrm{~mm} / 5$ day. Moreover, the heavier-cloud areas shown in Fig. 3 coincide approximately with the heavier-rainfall areas. From the good coincidence of cloud and rainfall in area and amount, it is inferred that a large amount of precipitation falls also within the cloud zone over the continent and sea, where rainfall data are not available. By this inference, it may be said that the cloud belt associated with the Baiu Front is a heavy rainfall zone, and tracing the time series in Fig. 4, both the heavy rainfall zone and the heavy cloud belt together shift northwards slowly at the beginning of this season, but rapidly at the end of it.

Looking at the rainfall distribution in more detail, the maximum rainfall area is found over southwest Japan at the last stage of the Baiu season. It is supposed that the Baiu Front would be the most active there at this stage. In this most active Baiu Front, heavy rainfalls are concentrated in a few small areas. In other words, daily or hourly rainfall distribution (although no figure is shown here) are characterized by mesoscale concentration. Such rainfall is caused apparently by mesoscaleorganized cumulus convections.

Next, we will make an estimate of the vertical velocity within the rainfall zone. It is possible to estimate upward motion kinematically from observed wind in general. In the present case, however, vertical velocity was estimated directly from rainfall 

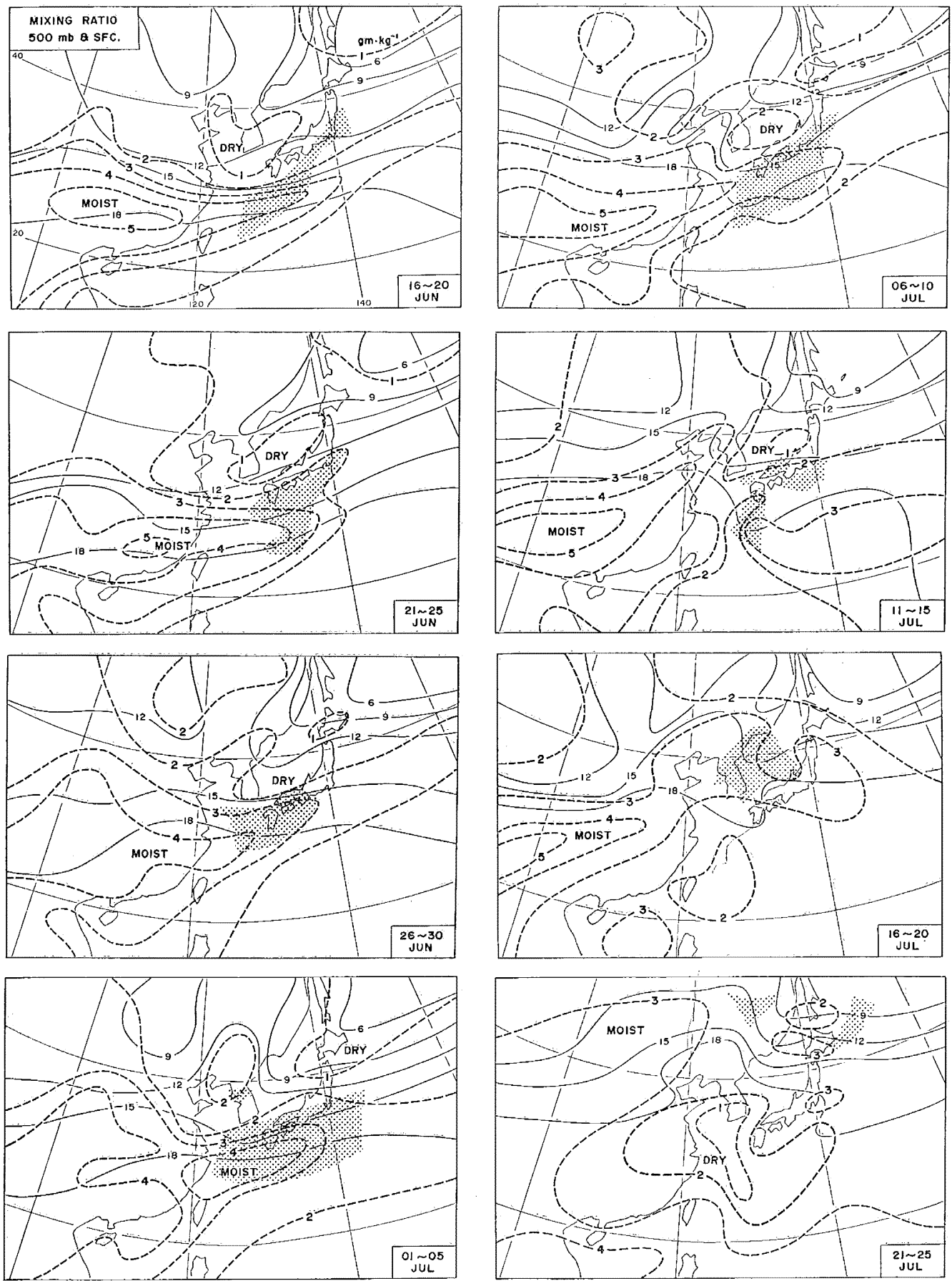

Fig. 5. Distribution of mean mixing ratio during the period from June 16 to July 25,1968 . Solid and dashed lines indicate the isolines of the surface and $500-\mathrm{mb}$ surface mixing ratios $\left(\mathrm{gm} \cdot \mathrm{kgr}^{-1}\right.$ ) respectively. Stippled area shows the area of heavy rainfall exceeding $50 \mathrm{~mm}\left(5 \mathrm{day}^{-1}\right)$. 
amount because the aerological observation network under consideration is not so dense to estimate upward motion in a narrow rainfall zone. The amount of precipitation is calculated by $P=\frac{-1}{g} \int \frac{F^{*}}{p} \omega d p$, where $F^{*}$ is given as $F^{*}=q_{s} T\left(\frac{L R-C_{p} R_{v} V}{C_{p} R_{v} T^{2}+q_{s} L^{2}}\right)$ (HALTINER, 1971). We assume the parabolic distribution of vertical velocity as

$$
\omega=\omega_{0}\left\{1-\left(\frac{p-600}{400}\right)^{2}\right\}
$$

where $\omega_{0}$ is the maximum upward velocity at the middle troposphere. Since $F^{*}$ is evaluated by using the mean sounding within the heavy rainfall area assuming saturation throughout the layer, we can estimate $\omega_{0}$ from the observed value of precipitation $P$. The vertical velocity thus obtained, which corresponds to the rainfall amount of $300 \mathrm{~mm} / 5$ day, reaches to $21 \mathrm{mb}^{-1}$ hour $^{-1}$ at the middle troposhere and the corresponding convergence at the lowest troposphere reaches to $1.3 \times 10^{-5} \mathrm{sec}^{-1}$ within the front near southwest Japan. These values are very large for 5-day mean, and show clearly the existence of persistent convective motion there.

In this section, it was pointed out that the belt-shaped zone of maximum cloudiness coincides with the heavy rainfall areas. Thus the Baiu Front may be called a large-scale convergence zone.

\section{Moist tongue in the Baiu Front}

By synoptic analysis of the active Baiu Front, it has been known that there is a narrow middle troposheric moist zone, the so-called "moist tongue", within the frontal zone and that this is probably formed through vertical transport of water vapor by active cumulus convections (Matsumoto et al., 1971). As noted in the previous section, the large-scale mean frontal zone extends along the northern boundary of the tropical-monsoon airmass characterized by high humidity and high temperature. It is, therefore, an interesting problem whether this moist tongue is found in the mean Baiu Front in general.

The 5-day mean mixing ratio maps during the analyzed period are presented in Fig. 5. In the figure, the isolines for the mixing ratios at the surface and $500-\mathrm{mb}$ surface are indicated by thin solid and dashed lines respectively. Stippled areas indicate areas of heavy rainfall exceeding $50 \mathrm{~mm} / 5$ day. The tongue-shaped $500-\mathrm{mb}$ moist area, elongating from the moist area over the south China Continent, protrudes east-northeastwards to the vicinity of the Japan Islands. The tip of the moist tongue is superposed on the heavy rainfall area over southwest Japan during the Baiu season. The axis of this mid-tropospheric moist zone coincides well with the axis of the belt-shaped cloud zone in Fig. 3. Moreover, a strong gradient of 500-mb mixing ratio is recognized along the south and north boundaries of the heavy rainfall area or belt-shaped cloudy zone. In other words, the $500-\mathrm{mb}$ moist area coincides well with the frontal cloudy zone.

On the other hand, we cannot find such a maximum zone of the mixing ratio at the surface, but a vast area of almost uniform high mixing ratio to the south of heavy rainfall areas. It is supposed that the $500-\mathrm{mb}$ moist zone is closely related to convective motions in the convergence zone. One may, however, regard the moist tongue itself and the associated heavy rainfall as due to horizontal advection of water 

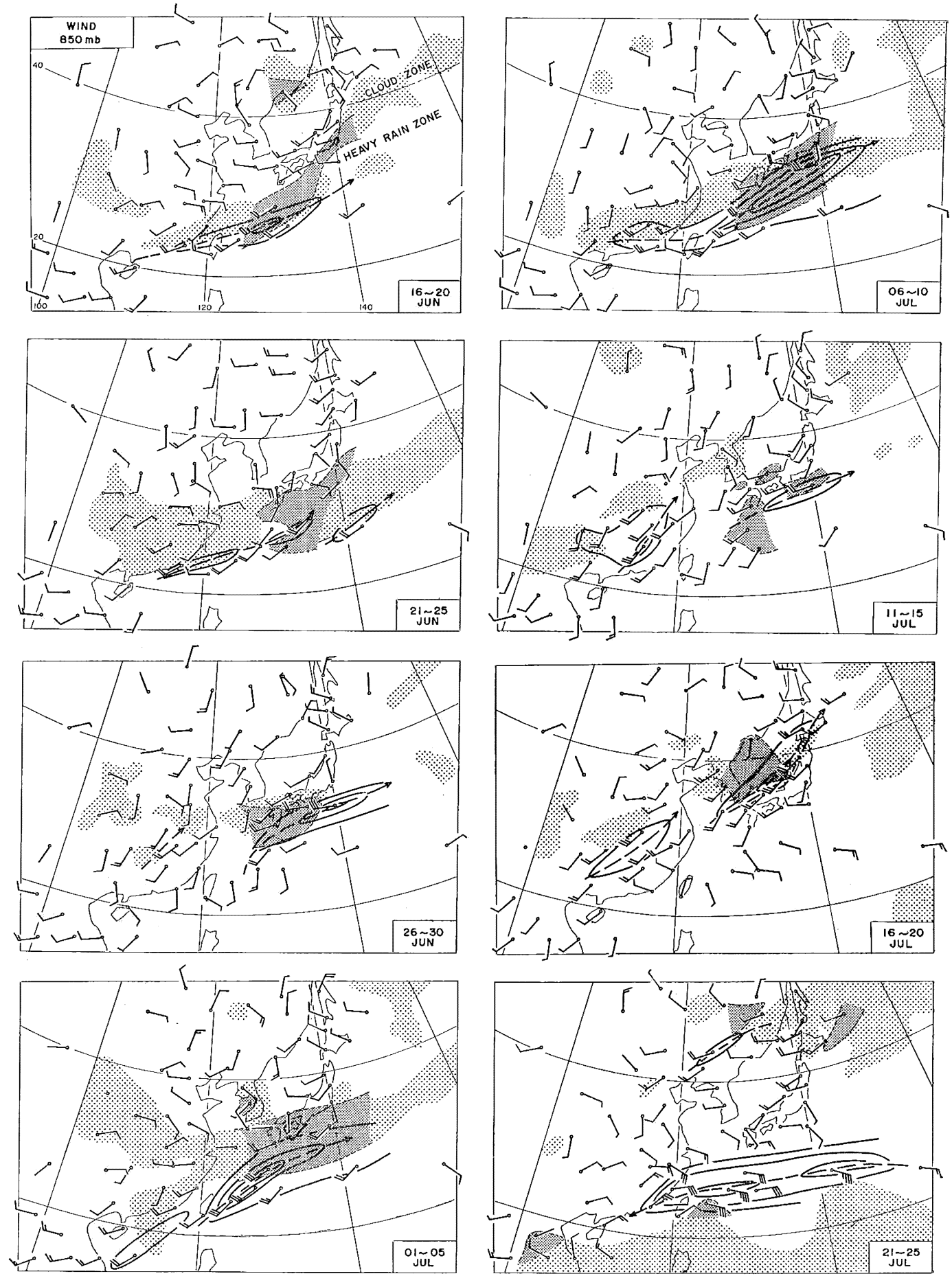

Fig. 6. Mean $850-\mathrm{mb}$ wind fields during the period June 16 to July 25, 1968 . Isotachs for 20,25 and 30 knot are presented by solid lines. Thick dashed line indicates the axis of $850-\mathrm{mb}$ strong wind. Thin stippling and dense stippling areas show a heavy cloud zone and a heavy rainfall area respectively. 
vapor from an upstream region. In practice, let us estimate the zonal component of horizontal advection of water vapor, $\frac{1}{g} \int_{500 \mathrm{mb} b}^{P_{S E C}} u \frac{\partial q}{\partial x} d p$. The largest value of $5 \mathrm{~mm} /$ day $\left(0.5 \mathrm{gr} \cdot \mathrm{cm}^{-2} \cdot\right.$ day $\left.^{-1}\right)$ is obtained on the south side of a heavy rainfall area, and the value obtained in a maximum rainfall area is far less than that. Consequently, it is impossible to adequately explain the large amount of precipitation within the Baiu Front simply by the horizontal advection of water vapor along the middle tropospheric moist tongue*.

Considering the above, the role of horizontal advection of water vapor is subordinate in the formation of a moist tongue in a large-scale Baiu Front. It may be more appropriate to consider that the upward convective transport of water vapor plays an essential role in the formation of a moist tongue ${ }^{* *}$.

\section{Low-level jet stream in the Baiu Front}

It has often been pointed out that the low-level jet is closely related to heavy rainfall in the Baiu Front. Mean field analyses of the active Baiu Front revealed the existence of a super-geostrophic strong wind core in the lower troposphere (i.e., the low-level jet stream) along the front and the close relation between this jet axis and the medium-scale disturbances embedded the Baiu Front. Matsumoto and Ninomiya (1971) and MATSUMOTо (1972) studied the mesoscale structure of the low-level jet associated with heavy rainfall and emphasized that the low-level jet is characterized by an ageostrophic wind field and that its formation is supposed to be due to convective motion. In this section, we will examine large-scale aspects of the mean low-level wind of the Baiu Front in relation to heavy rainfall as mentioned above.

Fig. 6 presents $850-\mathrm{mb}$ mean wind field during the analyzed period. In the figure, the maximum cloudiness areas and the heavy rainfall areas are shown by thin and dense stipples respectively. A thick dashed arrow indicates the axis of strong wind $* * *$. Solid lines are isotachs for 20, 25 and 30 knot. Throughout the Baiu season, strong winds are observed along the cloud zone. The strongest mean wind velocity, amounting to $30 \mathrm{knot}$, is found in the vicinity of the Japan Islands at the last stage of the Baiu season, when the rainfall is most intense (see Fig. 4). The strong cyclonic wind shear, i.e., a positive vorticity of $2 \sim 3 \times 10^{-5} \mathrm{sec}^{-1}$ is found on the north side of the jet's axis. Looking into the location of the strong wind axis relative to the heavy rain area or cloud zone throughout the analyzed period, we notice that the axes of the low-level jet are located always along the south side of the heavy rainfall area or cloud zone. Since a heavy cloud zone is considered as a heavy rainfall area (see section 2), it may be said that the mean low-level jet is closely related to the heavy rainfall. The low-level jet moves northwards according to the northwards shifts of the heavy rainfall area with the progress of the season. In other words, this jet stream does not appear at a certain geographical region, but at a specific region where heavy rainfalls take

* The zonal gradient of mixing ratio near the surface is very weak.

** By synoptic analysis, OTANI (1954) has shown before that a moist tongue and associated heavy rainfalls occur ahead of a belt where SE and SW currents converge.

*** Since the steadiness of the wind $\bar{V} /|\bar{V}|$ and the standard deviation of the zonal component in the vicinity of the jet axis is about $90 \%$ and several meters per sec respectively, it may be said this mean low-level jet on 5-day mean field is fairly steady. 

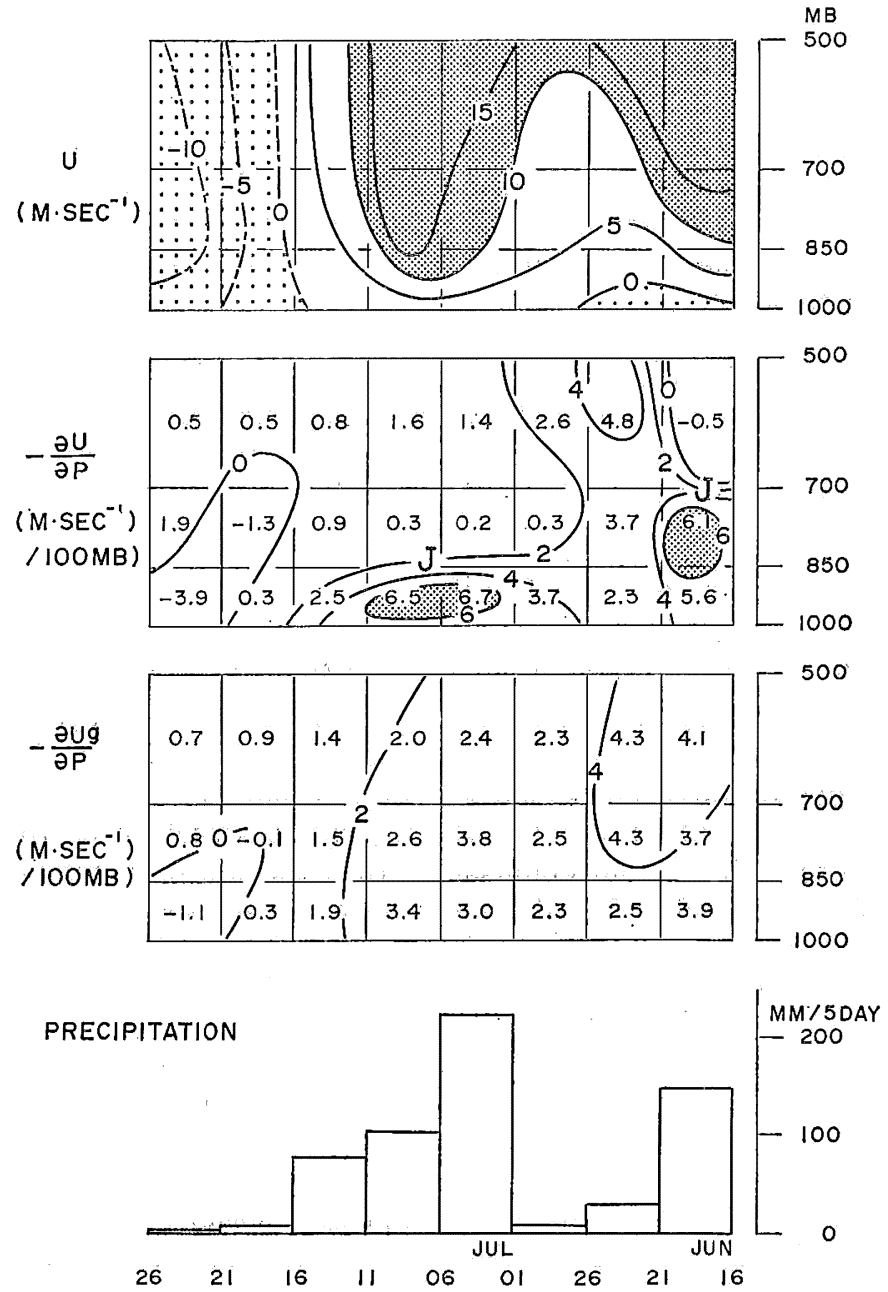

Fig. 7. Upper: Time section of the vertical profile of 5-day mean zonal wind at Naze (47909) during the period from June 16 to July 25, 1968.

Middle: Upper figure-vertical shear of 5-day mean observed zonal wind at Naze. Stippled area shows the layer of strong shear exceeding $6 \mathrm{~m} \cdot \mathrm{sec}^{-1}$ $100 \mathrm{mb}^{-1}$. J denotes the core of the low-level jet. Lower figure-vertical shear of 5-day mean geostrophic zonal wind calculated objectively from geopotential heights of 4 stations, which are shown in Fig. 1.

Lower: Time section of the precipitation amount at Naze during the same period.

place. This feature of the low-level jet suggests that its generation does not depend on topographical effect*, but mainly on the convective activity in the heavy rainfall area.

* It was reported that a kind of low-level jets observed over the east sides of the Rocky mountains and the African Continent is generated by topographical effect of the mountain or the continent. (WEXLER, 1961, HoEcKer, 1963, Findlater, 1969) 
Now, we will examine the vertical wind profile of the low-level jet. In the upper figure in Fig. 7 is shown the vertical distribution of 5-day mean observed zonal winds at Naze (47909). This station is located over the sea, where topographical influence would be weak. The densely stippled area indicates a strong westerly layer and the thin stippled area shows easterlies in the summer season, when this station is covered by the Northern Pacific subtropical anticyclone. The strong westerly layer protrudes to the lower troposphere during heavy rainfall periods at Naze (see the time variation of rainfalls presented in the lowest figure in Fig. 7.). There are apparently low-level strong wind cores at the $850-\mathrm{mb}$ surface or near the lower boundaries of the downwards protruding strong westerlies. It is noteworthy that an intimate relation between the low-level jet and the heavy rainfall is found in the vertical wind profile as well as in the wind field at the $850-\mathrm{mb}$ surface.

In order to understand the character of the low-level jet, it is more adequate to compare the actual vertical wind shear with the geostrophic one rather than compare the actual wind speed itself with the geostrophic wind speed. The second figure in Fig. 7 presents the vertical shear of the zonal component of observed wind at Naze and the third figure presents that of the geostrophic wind calculated by using the geopotential height of four aerological stations which surround Naze (see Fig. 1). In the figure of actual wind shear, the low-level jet cores are denoted by $J$, while the stippled area indicates the layer of strong shear exceeding $6 \mathrm{~m} \cdot \mathrm{sec}^{-1} \cdot 100 \mathrm{mb}^{-1}$. It is clearly seen that the observed wind shear below the jet core is extremely strong, while the one above the jet core is very weak. On the other hand, geostrophic wind shear is almost uniform through the convective layer. In other words, the geostrophic wind speed increases linearly with height, while the observed wind speed is almost uniform throughout the thick convective layer. A comparison of the actual wind shear around the low-level jet core with the geostrophic wind shear there shows that the latter is less than half of the former below the jet core and that the actual shear above the jet core is very weak in spite of considerably strong geostrophic shear. It should be emphasized that the vertical shear of the observed mean lowlevel jet deviates remarkably from that of the geostrophic wind during the heavy rainfall periods, i.e., the mean low-level jet has an ageostrophic component. The layer of uniform U-comopnent (the upper figure) above the mean low-level jet core suggests that the convective mixing of horizontal momentum results in an increase in wind speed at lower levels and a decrease in the higher layers. From dynamical considerations, MATsumoto and NiNomIYA (1971) suggested that the unbalance between the pre-existing mass field and the velocity field of the ageostrophic low-level jet induces a solenoidal circulation around the jet core, and further maintains the successive severe rainfalls within a narrow area in the Baiu Front.

\section{The stratification of the Baiu Front and development of medium-scale disturb- ances}

It is known that medium-scale disturbances with a wave-length of about $1,000 \mathrm{~km}$ and a period of about one day develop and/or propagate successively along the Baiu Front. The kinetic energy of these medium-scale disturbances is concentrated within the lower troposphere to the north of the low-level jet stream (MATsumoto et al., 1971). Favorable conditions for the development of these disturbances are supposed to be prepared inside of the Baiu Front. In order to confirm the above, we will study in 

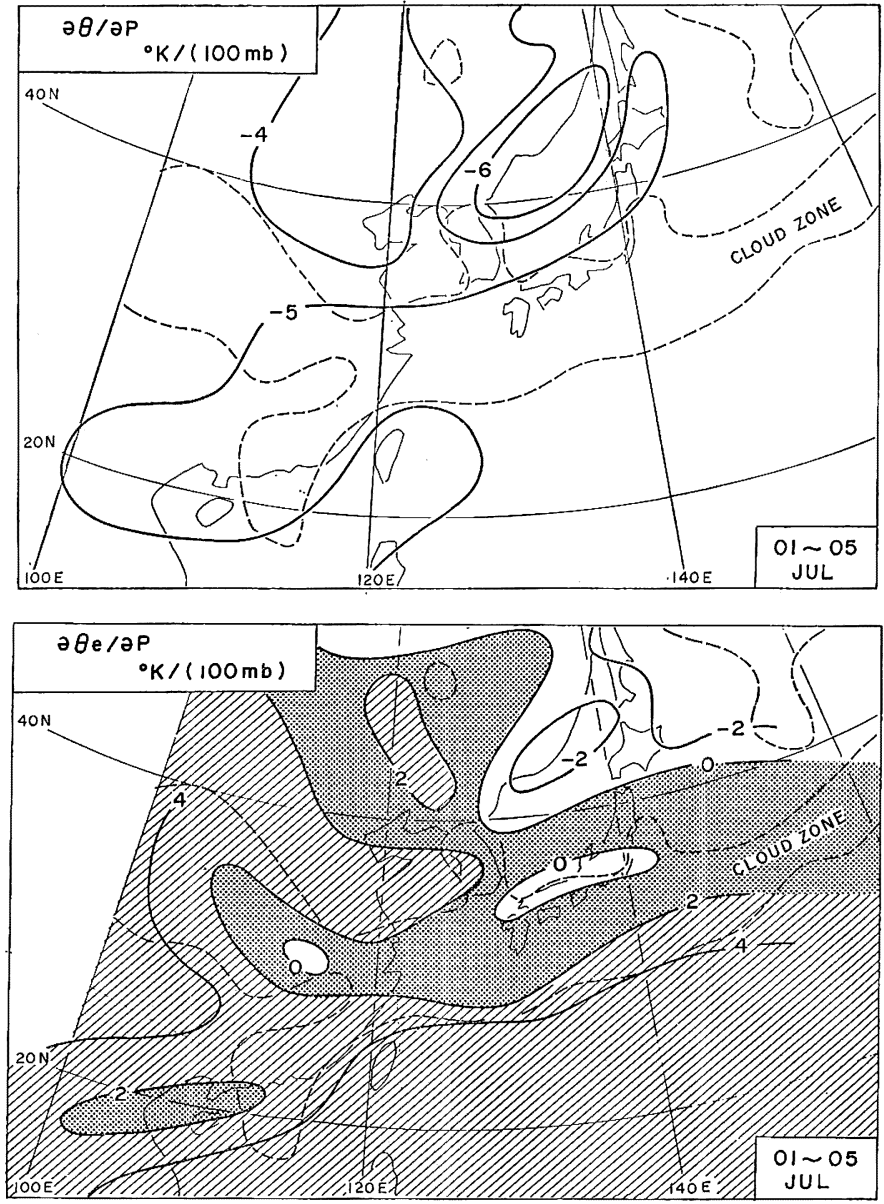

Fig. 8. Distribution of mean vertical stability during the period from July 1 to July $5,1968$.

Upper: Vertical gradient of potential temperature $(\partial \theta / \partial p)_{700-\mathrm{SFC}}$.

Lower: Vertical gradient of equivalent potential temerature $\left(\partial \theta_{e} / \partial p\right)_{700-\mathrm{SFC}}$.

this section the thermal stratification in the vicinity of the front.

Distribution of mean vertical stability in the lower troposphere from July 1 to July 5 is shown in Fig. 8 as an example of the Baiu season. The upper figure shows the distribution of the vertical gradient of potential temperature $(\partial \theta / \partial p)_{700-s F o \text {, }}$ and the lower figure, that of equivalent potential temperature $\left(\partial \theta_{\theta} / \partial p\right)_{r 00-s F o \text {. As for }}$ the vertical gradient of potential temperature, the whole area under consideration is negative, i.e., stable for a dry air parcel. As for that of equivalent potential temperature, on the contrary, the stable layer is confined to the polar airmass region and to small areas in the heavy cloud zone, whose boundary is indicated by dashed lines in the figure. The remaining area is positive, i.e., unstable for the saturated air parcel. In short, the thermal stratification of the lower troposphere over the Far East is conditionally unstable except in the polar airmass region spreading over the Maritime 
and the northern Pacific. The densely stippled area in the lower figure indicates less unstable stratification $\left(0<\frac{\partial \theta_{e}}{\partial p}<2\right)$ than the hatched area $\left(2<\frac{\partial \theta_{e}}{\partial p}\right)$. It is an interesting fact that higher values of vertical instability are found to the south of the Baiu Front over the southwest Pacific, rather than inside the front, where intense rainfalls take place. It should be noted that the stratification within the heavy rain zone of the Baiu Front is almost neutral. The stratification near the wet-adiabatic lapse rate observed over the west Japan Islands locates on the north side of the axis of the low-level jet in the Baiu Front. These features reveal the character of the convective mixing in the troposphere there.

According to theoretical studies by several authors such as GAMBo (1970a,b), TokiokA (1970), one may find the development of baroclinic unstable waves whose wave lengths are about $1,000 \mathrm{~km}-2,000 \mathrm{~km}$ in middle latitudes in the atmosphere where the Richardson number $R_{i}=-\alpha \frac{\partial 1_{n} \theta}{\partial p} /\left(\frac{\partial u}{\partial p}\right)^{2}$ is of the order of magnitude of unity. Since the atmosphere within the Baiu Front is approximately saturated, the Richardson number $R_{i}=-\alpha \frac{\partial 1_{n} \theta}{\partial p} /\left(\frac{\partial u}{\partial p}\right)^{2}$ should be replaced by $R_{i}=-\alpha \frac{\partial 1_{n} \theta_{e}}{\partial p} /\left(\frac{\partial u}{\partial p}\right)^{2}$. As noted in section 5, strong vertical shear is concentrated near the surface within the Baiu Front; therefore, the Richardson number is expected to be considerably small in the frontal zone. The magnitude of $R_{i}$ obtained is 0 to 3 in heavy rainfall areas along the front. Although these values are not always less than unity, we may conclude that favorable conditions for the growth of medium-scale disturbances are prepared within the narrow zone to the north of the axis of the low-level jet stream. It should be also noted that the medium-scale disturbances organize cumulus convection within the Baiu Front.

It is difficult, however, to determine conclusively whether these disturbances embedded in the Baiu Front are modified baroclinic waves proposed by theoretical studies or numerical experiments mentioned above, unless dynamical structures are analyzed in more detail. Reserving the conclusion for further studies, let us look the existence of these disturbances on vertical time section presented in Fig. 9. This figure shows the time section from 09 LST July 8 to 21 LST July 12, 1968, at Fukuoka $(47807)^{*}$ located in western Japan, where the active Baiu Front is almost steady for this period. In the figure, the moist layer, in which relative humidity exceeds $90 \%$, is indicated by hatched and the northerly wind layer, by stippling. From the periodic variation of meridional wind component and humidity, lower tropospheric disturbances, with a period of about one day, are remarkable. During periods of southerly wind, the deep moist layer reaches to the upper troposphere. The phase velocity and wave length of these disturbances are found to be about $50 \mathrm{~km} \mathrm{hour}^{-1}$ and about $1,000 \mathrm{~km}$ respectively.

\section{Influence of convective warming on thermal and wind fields in the upper tropo- sphere over the Baiu Front}

In previous sections, it has been often pointed out that the Baiu Front is a narrow zone of intense cumulus activities. We naturally expect to find there the

\footnotetext{
* This station is indicated in Fig. 1 .
} 


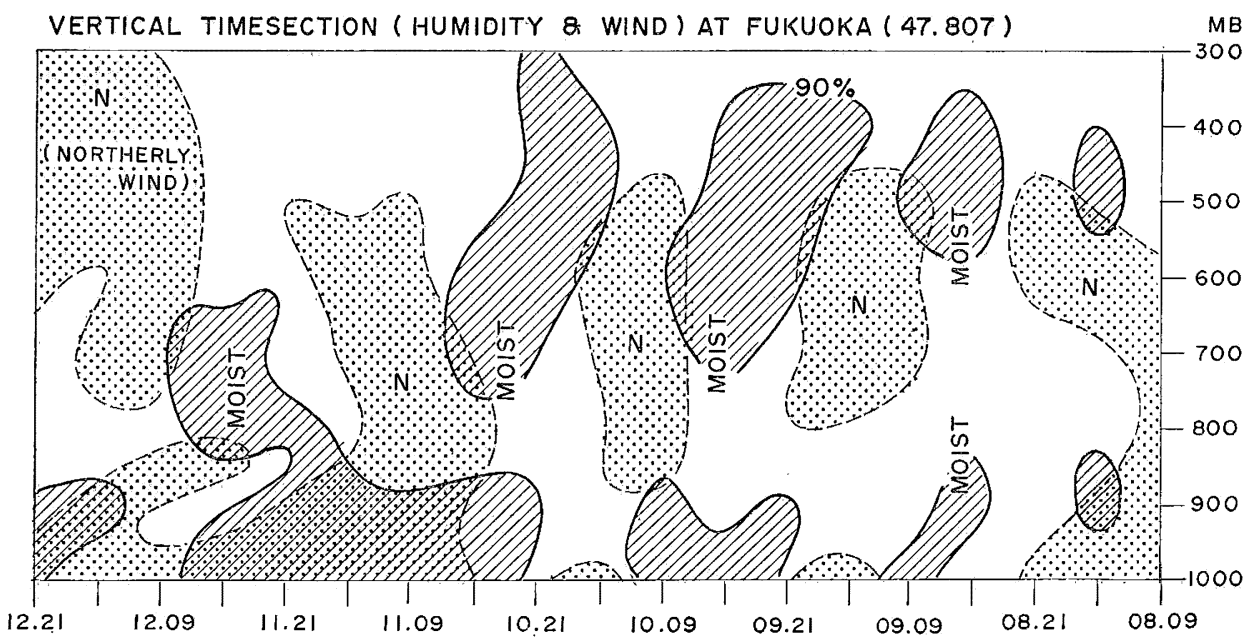

Fig. 9. Vertical time section at Fukuoka (47807) during the period from 09 LST July 8 to 21 LST July 12,1968 . Hatched area shows the layer of relative humidity exceeding $90 \%$, stippled area the layer of northerly wind.

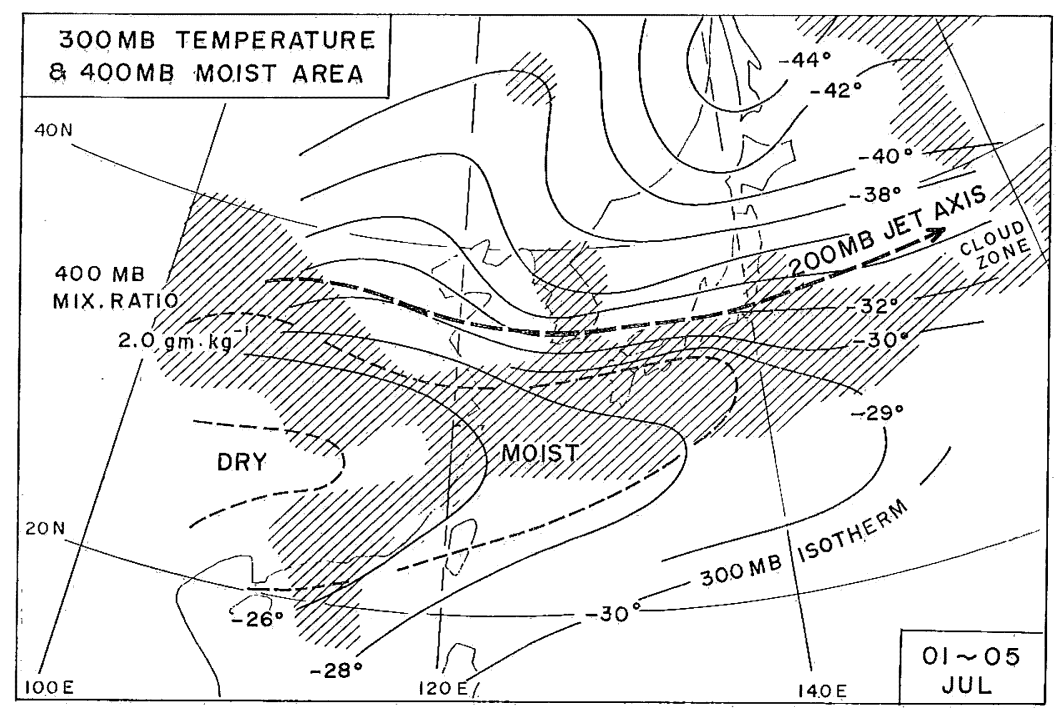

Fig. 10. Mean thermal field at $300-\mathrm{mb}$ for the 5-day period from July 1 to July 5,1968 . Hatched area indicates the heavy cloud zone. The area bounded by broken lines is the $400-\mathrm{mb}$ moist area in which the mixing ratio exceeds 2 $\mathrm{gr} \cdot \mathrm{kg}^{-1}$.

characteristic features indicating the influence of convective activities in the largescale field. From this viewpoint, it is our purpose in this section to study moisture, thermal and wind fields in the upper layer in the vicinity of the Baiu Front.

As an example, the 5-day mean chart for the 5-day period from July 1 to July 5, 1968, is shown in Fig. 10, in which thin dashed and solid lines indicate the isoline 
of mixing ratio of $2 \mathrm{gr} \cdot \mathrm{kg}^{-1}$ at the $400-\mathrm{mb}$ surface and $300-\mathrm{mb}$ isotherm respectively. In the figure, the thick dashed arrow indicates the axis of the 200-mb jet stream and the hatched area the maximum cloudiness zone. The northern edge of the $400-\mathrm{mb}$ moist region coincides approximately with the zone of concentrated thermal gradient and also with the north boundary of the belt-shaped cloud zone. The 400-mb moist area, where a deep moist layer is formed through the deep layer from the surface to the upper troposphere (see the $500-\mathrm{mb}$ moist area in Fig. 5), would indicate the influence of penetrative convection.

It is naturally inferred that the latent heat released in the condensation process and the upward transport of sensible heat cause remarkable middle and/or upper tropospheric convective warming* inside the cloud zone, since the amount of precipitation there is as much as $300 \mathrm{~mm} / 5$ day. This warming would consequently increase the thermal gradient along the northern boundary of the zone of convective warming. We can find, actually, the concentration of the $300-\mathrm{mb}$ isotherm along the north edge of the cloud zone (Fig. 10).

As mentioned above, the strong horizontal thermal gradient in the middle and upper troposphere is due to the convective warming to the north of the cloudy zone. This strong thermal gradient would result in an increase in wind speed along the north edge of the convective warming area through the thermal wind relation. In order to confirm this inference, we will examine the upper wind shear in the vicinity of the Baiu Front. Fig. 11 shows the mean vertical wind shear between 200- and $300-\mathrm{mb}$ surfaces during the Baiu season. In the figure, the belt-shaped maximum cloudiness zone is indicated by enclosing with a dashed line and the heavy rainfall area by dense stipples. Strong shear is apparently found to the north of the cloud zone and/or the heavy rainfall area. In other words, 200-mb wind speed is intensified to the north of the heavy cloud zone. In short, it may be said that the mid-upper convective warming in heavy rainfall induces the increasing of wind speed ${ }^{*}$ in the overlying layer to the north of it.

From the discussions above, we should like to conclude that the appearance of a locally intensified upper jet core is a phenomenon simultaneous with heavy rainfall rather than one preparing synoptic conditions favorable for the heavy rainfall.

\section{Water vapor budget in the vicinity of the Baiu Front}

A deep moist layer is formed within the Baiu Front by persistent cumulus: activities. Abundant water produced by condensation through ascending motion falls out as heavy precipitation there. One may naturally wonder from where the large amount of water vapor is supplied, which maintains the frontal activities. In order to clarify this problem, we will, in this section, examine the field of horizontal water vapor flux in the Far East, the amount of water vapor supplied from the sea surface to the atmosphere, and the water vapor budget in the vicinity of the Baiu Front.

* As for the convective warming and the related phenomena over the convective region, the papers by MANABE (1956), NinomiYA (1971 a and b), RAO and HASSEBRocK (1972) are to be referred to.

** Typical examples of the intensification of the upper' jet to the north of the convective area are shown by Ninomiya (1971 b), Ninomiya and AkiYama (1971). 

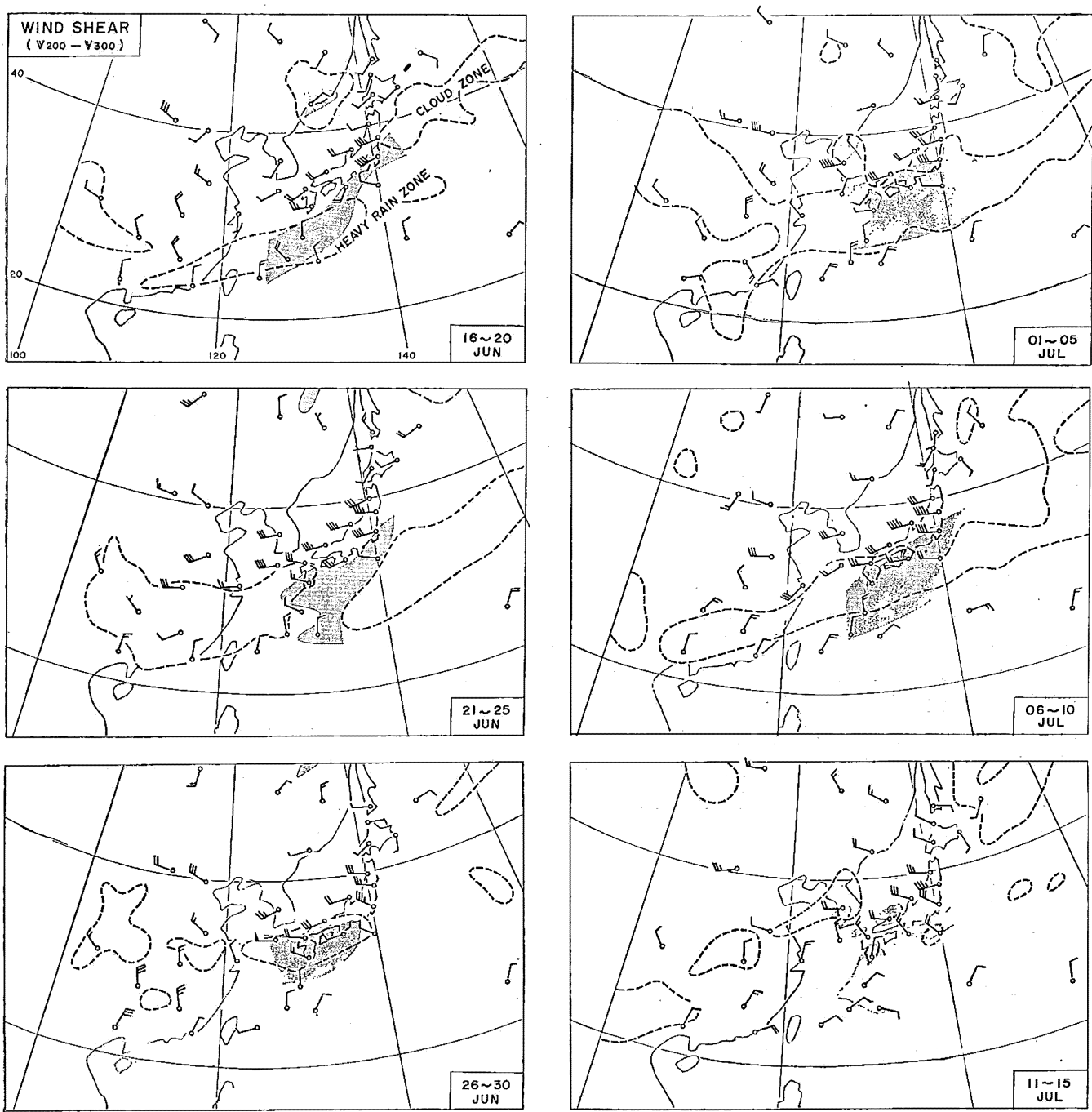

Fig. 11. Distribution of 5-day mean vertical wind shear between 200-and 300-mb surfaces during the period from June 16 to July 15, 1968. The area bounded by dashed lines and the densely stippled area indicate the heavy cloud zone and the heavy rainfall area respectively.

\subsection{Horizontal water vapor fux in the vicinity of the Baiu Front}

Many climatological studies have been made on horizontal transport of water vapor over the Far East in the summer rainy season. It was found out that a predominant water vapor flow shaping a belt-like zone extends east and west over East Asia, coinciding with the maximum cloudiness zone (MURAKAMI, 1959 and ASAKURA, $1971 \mathrm{~b}$ ). In the present case, we will examine the water vapor flux on the actually observed values at each station, not on a smoothly interpolated field as treated by the authors mentioned above. 

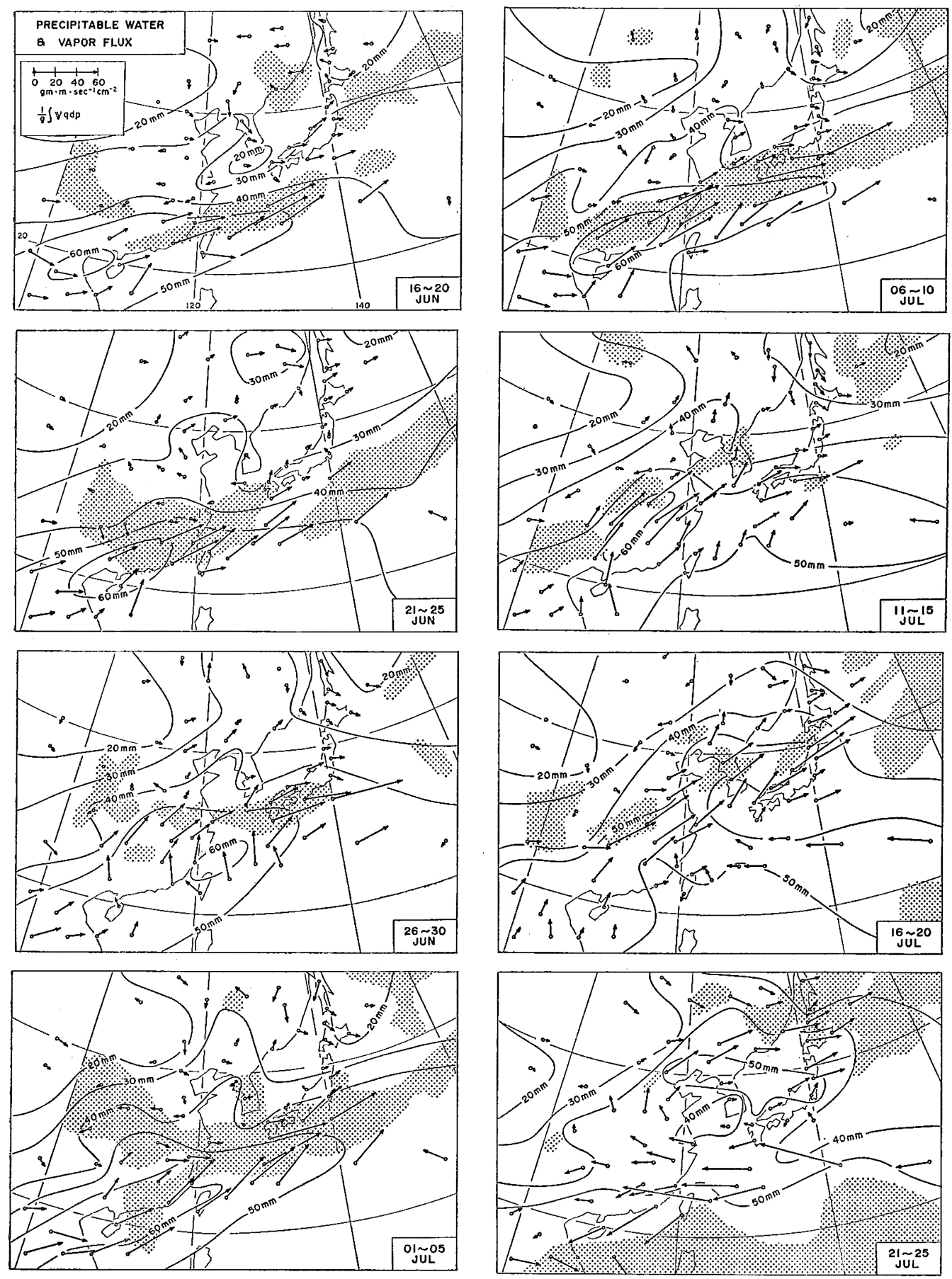

Fig. 12. Distribution of precipitable water (solid line) and horizontal water vapor flux (arrow) during the period from June 16 to July 25, 1968. Stippled area presents the heavy cloud zone. 
Fig. 12 shows the distributions of precipitable water amount in the air column from the surface to $500-\mathrm{mb}, \frac{1}{g} \int_{500 \mathrm{mb}}^{P_{S F C}} \bar{q} d p$ and the horizontal water vapor flux at each station, $\frac{1}{g} \int_{500 \mathrm{mb}}^{P_{S F C}} \overline{q V} d p$ where $P_{S F \sigma}$ is the surface pressure at the station, $q$ is the specific humidity and the bar denotes time-averaging over each 5-day during the analyzed period*. It is clearly seen that a large amount of water vapor is transported along the maximum cloudiness zone, which is indicated by stipples in the figure. The axis of the maximum water vapor flux coincides well with the axis of the mean low-level jet in Fig. 6, which extends along the south side of the cloudy zone. Tracing throughout the season, it is found that the highest values of transport appear at the last stage of the Baiu season, when the low-level jet reaches to maximum intensity. From the above, it is supposed that the low-level jet contributes mainly to increase the water vapor transport. (The mixing ratio does not change remarkably as compared with wind speed.) It is an important fact that the water vapor flux increases eastwards along the Baiu Front. In other words, $\frac{\partial u q}{\partial x}$ is positive, i.e., longitudinal divergence of the zonal moisture flux in the frontal zone ${ }^{* *}$. This fact disproves the hypothesis that the horizontal transport of moisture from regions to the windward of the Baiu Front maintains the heavy rainfall over the Japan Islands. Another important feature found in Fig. 12 is the strong northward transport of moisture to the south of the frontal zone. We find a negative value of $\frac{\partial v q}{\partial y}$ (i.e., meridional convergence) within the frontal zone. This meridional convergence would sustain both longitudinal moisture divergence and strong precipitation. We will make quantitative analysis on the water vapor budget later.

The area of abundant precipitable water spreads over the south China Continent, the south China Sea and Formosa, protruding along the front with the zone of maximum water vapor flux. This area coincides fairly well with the $M$ and $T^{\prime}$ airmass area (see Fig. 3), rather than with the 500-mb moist area (see Fig. 5). In other words, the distribution of precipitable water depends mainly on the lower tropospheric moisture field.

Roughly speaking, a large amount of water vapor in the lower layer south of the front is transported along the front by a southerly low-level jet. Next, let us examine the influence of the ocean on the formation of the vast moist airmass to the south of the Japan Islands.

\subsection{Water vapor supply from the sea surface}

As one of the source regions of moisture for the Baiu (the rain in the pre-summer season over Japan), the western Pacific Ocean has been mentioned by many authors. For instance, Murakami (1959) showed that the moisture source should be found east of Formosa in the western Pacific at the end of the Baiu season, where evaporation amounts to about $15 \mathrm{~mm}$ per day. AsAKura (1971 a) pointed out also that the source

* The surface elevation is taken into account by considering the surface pressure for the upper limit of vertical integration.

** The zonal direction is indicated by $x$ and the Baiu Front is almost parallel to the $x$-direction. 


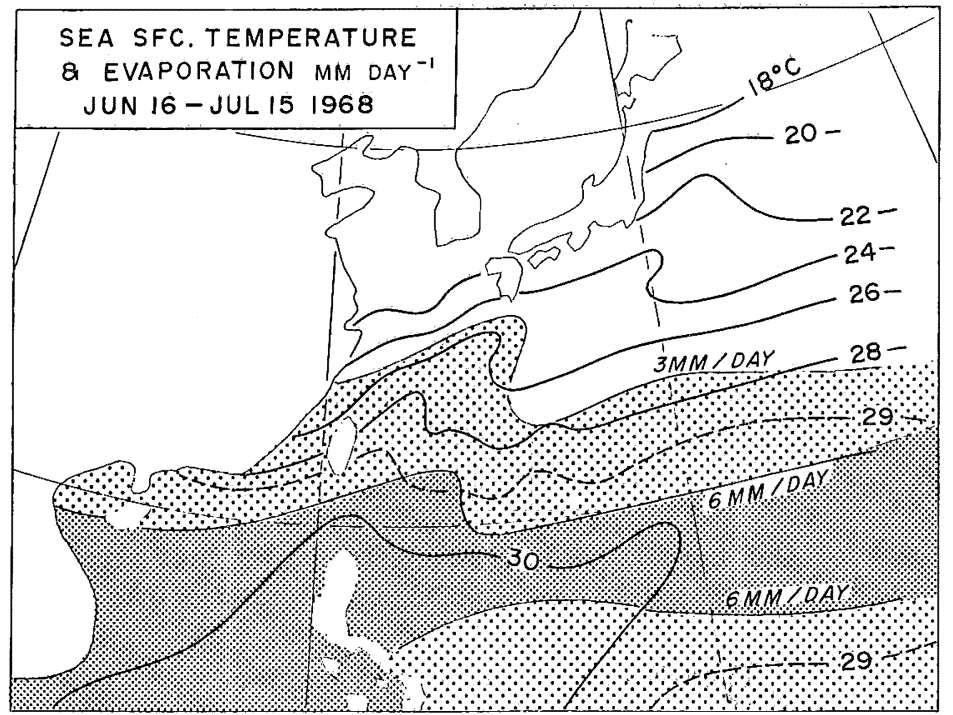

Fig. 13. Distributions of mean sea surface temperature and evaporation amount during the 30-day period from June 16 to July 15, 1968.

of water vapor is found over the ocean covered by the subtropical anticyclone. We will estimate the evaporation from the sea surface by using Jacob's formula during the period under consideration.

In Fig. 13 are shown the distributions of mean evaporation obtained and mean sea surface temperature during the 30-day period from June 16 to July 15, 1968. The zone of maximum evaporation, indicated by dense stipples in the figure, extends east and west along the latitude circle. The large amount of evaporation there is mainly due to the high water temperature. The values obtained in the present case, however, are not so large as the value obtained by Murakami (1959). Still the amount of mean evaporation exceeds $8 \mathrm{~mm}$ day $^{-1}$ over the South China Sea and the Pacific in the vicinity of Formosa. The area of maximum evaporation protrudes northward to the south coast of the Japan Islands along the Kuroshio currents. These sea areas of active evaporation coincide fairly well with the area of high mixing ratio at the surface.

It may be said that evaporation from these sea regions plays an important role in forming the moist airmass over the ocean to the south of the Japan Islands. The moist air thus formed is transported by the strong southerly wind of the low-level jet into the Baiu frontal zone, and thus maintains convective activities. The heavy rainfall, however, can not be explained by the transport of water vapor only. In order to maintain frontal activities, or to feed cumulus convection, strong convergence of the water-vapor flux in the lower layer is necessary. Next, let us make budget analysis of water vapor in the vicinity of the Baiu Front, in order to clarify the relation between transport and convergence of water vapor. 


\subsection{Water vapor budget of the Bain Front}

Water vapor budgets are calculated on the polygonal areas $A, B$ and $C$, which are surrounded by the aerological stations as shown in Fig. 1. These areas are on the south China Continent, the East China Sea and the southwestern Japan Islands respectively (see Table 2 for the dimensions of these areas). The mean amount of

Table 2. Areal dimension of the areas where the water vapor budget is calculated.

\begin{tabular}{c|l}
\hline \hline area & \multicolumn{1}{|c}{ dimensions } \\
\hline A & $94.2 \times 10^{4} \mathrm{~km}^{2}$ \\
B & 72.3 \\
C & 31.8 \\
\hline
\end{tabular}

vapor outflow due to the northward component of vapor flux across the northern boundary and that of inflow across the southern boundary of the polygonal region,

$$
\begin{aligned}
& \frac{1}{g} \iint \overline{q v} d p d x \quad \text { and } \frac{1}{g} \iint \overline{q v} d p d x, \\
& \text { north boundary } \\
& \text { south boundary }
\end{aligned}
$$

and the amount of outflow due to the eastward component of vapor flux across the eastern boundary and that of inflow across the western boundary,

$$
\frac{1}{g} \iint \overline{q u} d p d y \quad \text { and } \frac{1}{g} \iint \overline{q u} d p d y
$$

east boundary west boundary

are evaluated at each area for each 5-day period during the analyzed period and the results for July 1-5 are shown in Fig. 14 a-c as an example. The abscissa is the amount of water vapor in- or outflow for a layer of 1-mb thickness and the numerals entered stand for its integrated values in the layer with indicated pressure depth.

On any of the figures is clearly shown the important role of the low-level jet in water vapor transport; that is, most of the vapor flux is accomplished within the lower layer. In particular, the strong northward component of vapor flux across the southern boundary of the areas is clearly recognized at the lowermost layer of areas $A$ and $B$. This reveals that the moist airmass which was modified over the subtropical ocean is transported into the frontal zone. On the other hand, outflow across the northern boundary is very small. (That is strong convergence of meridional vapor flux.) It is a fact common to the three areas $A, B$ and $C$ that the amount of outflow by the eastward component across the eastern boundary far exceeds that of inflow across the western boundary. (That is strong divergence of longitudinal vapor flux.) Therefore the strong inflow across the southern boundary does not only compensate for the longitudinal divergence, but also causes the total convergence within the areas.

In order to show the features of water budget throughout the Baiu season, the vertically integrated value of the transport and that of convergence for the three areas are presented in Fig. $15 \mathrm{a}-\mathrm{c}$. In the figure squares denote the areas and each side of the square indicates, clockwise, the northern, eastern, southern and western 


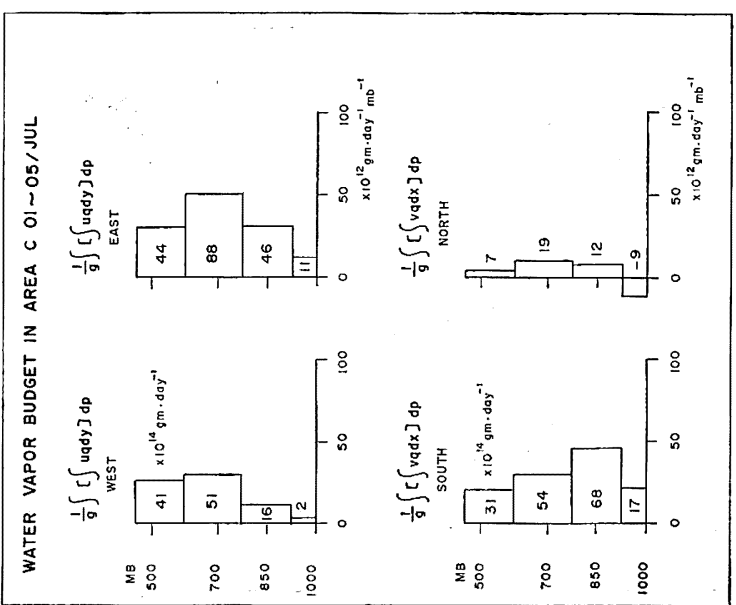

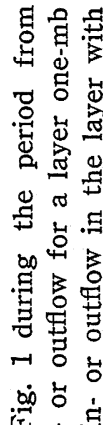
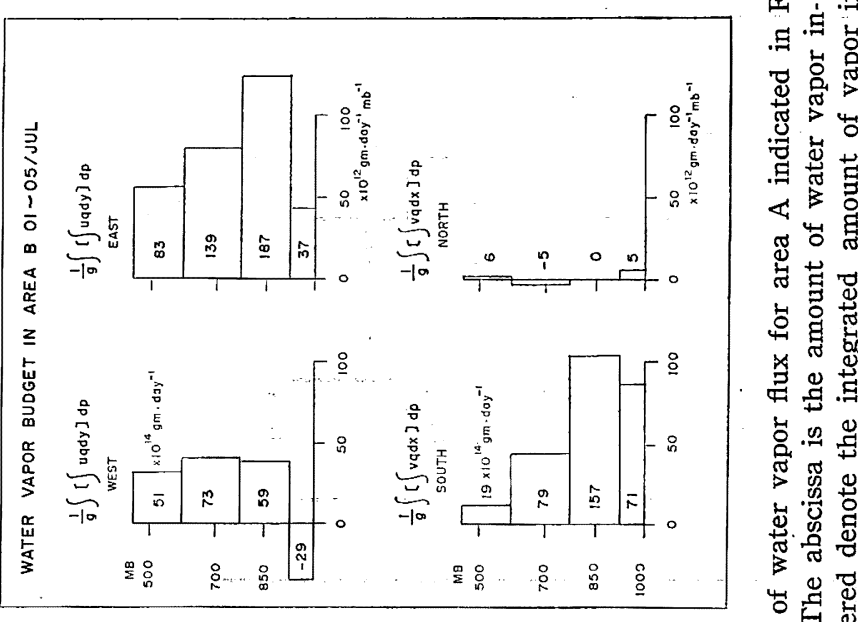

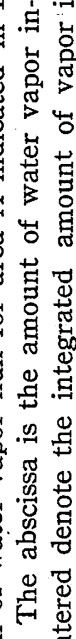

$\oplus \dot{0}$

ญ્ّ

薄葛

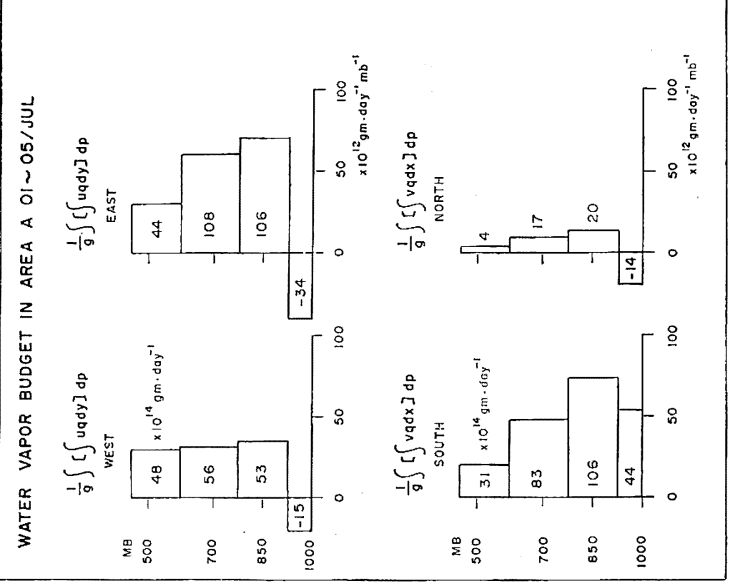

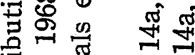

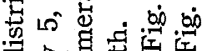

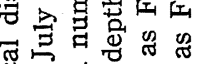

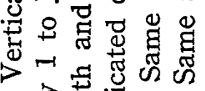
$>\rightarrow$ 象

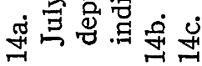

这

完完 

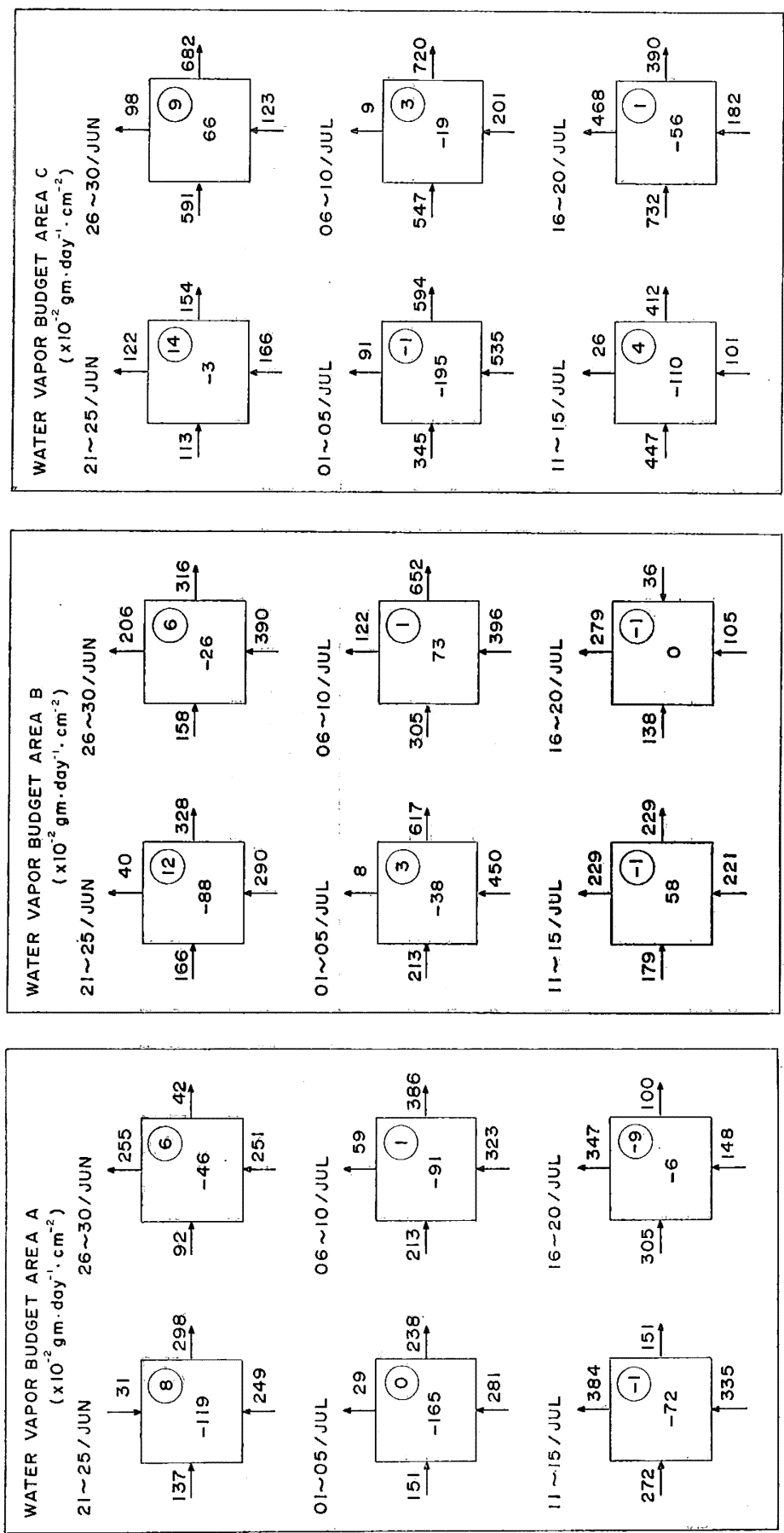

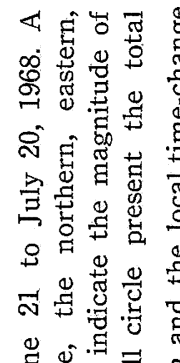

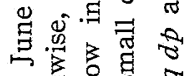

द

出 웜

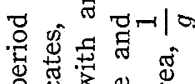

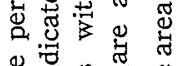

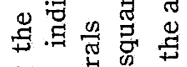

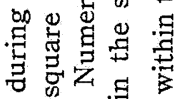

$\varangle \& \therefore \frac{0}{0}$

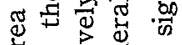

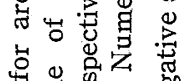

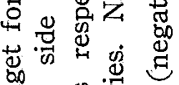

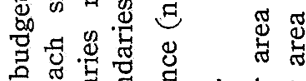

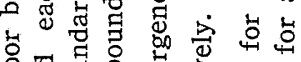

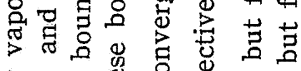

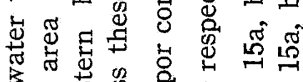

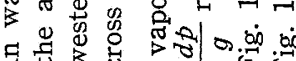

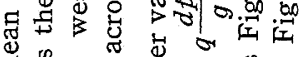

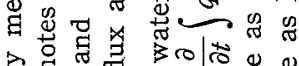
害总 以

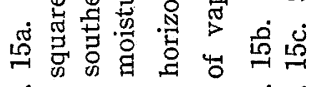
离 ف일 
boundaries respectively. Numerals with arrows indicate the vertically integrated values of flux across the north, west, south and east boundaries of the area. Numerals in a square and numerals in a small circle mean the sum of water vapor convergence within the area, $\int_{500 \mathrm{mb}}^{\dot{P}_{S F C}} \nabla \cdot q \boldsymbol{V} \frac{d p}{g}$ and the local time-change of vapor, $\int_{500 \mathrm{mb}}^{P_{S F C}} \frac{\partial q}{\partial t} \frac{d p}{g}$ respectively*. As seen in Fig. 15, the magnitude of the latter is negligibly small as compared with the former. It is clearly seen that the greater part of the strong vapor convergence is due to the strong inflow across the southern boundary of the area. At the middle of the Baiu season, the area of strong vapor convergence appears in area $A$ (south China), but at the last stage of the Baiu season, it shifts to area $C$ (western Japan). In other words, the zone of maximum convergence of vapor flux gradually shifts northwards with the frontal zone. The largest amount of vapor convergence in the figures, reaching nearly to $20 \mathrm{~mm}$ day $^{-1}$, is observed for the period July 1 to 5 in area C (i.e., western Japan), where intense rainfalls took place at the last period of the Baiu season.

Now, we will compare the observed value of precipitation with the convergence of water vapor. The relation between them is given by the continuity equation of the water-vapor,

$$
-\frac{1}{g} \int \nabla \cdot V q d p+E=P
$$

where $E$ and $P$ are evaporation and precipitation. Since area $C$ covers mainly western Japan, evaporation in that area may be considered insignificant. The maximum value of convergence of vapor flux is $1.95 \mathrm{gr} \cdot \mathrm{cm}^{-2} \cdot$ day $^{-1}$ (for the period from July 1 to July 5). This value coincides fairly well with the observed value of precipitation (see Fig. 4). Although no precipitation data are available over the China Continent, the existence of a cloud zone there suggests considerable precipitation there. The value of the convergence in area $A$ (the south China Continent) is $1.0 \mathrm{gr} \cdot \mathrm{cm}^{-2} \cdot \mathrm{day}^{-1}$. This will be enough to explain the precipitation there. Since area $B$ (the East China Sea) covers a sea area, we should take evaporation into consideration. From the distribution shown in Fig. 13, the mean amount of evaporation is estimated 3-4 mm $\cdot$ day $^{-1}$ (i.e., $0.3-0.4 \mathrm{gr} \cdot \mathrm{cm}^{-2} \cdot$ day $^{-1}$ ). The value of the moisture convergence in the middle Baiu season is $0.7 \mathrm{gr} \cdot \mathrm{cm}^{-2} \cdot \mathrm{day}^{-1}$. We evaluate the precipitation to be $1.0 \mathrm{gr} \cdot \mathrm{cm}^{-2} \cdot$ day $^{-1}$ (c.f. Fig. 4). It is interesting to note that there is a net divergence of water vapor in the last period of the Baiu season (July 11-15). During the period, the East China Sea becomes a source region of water vapor. From the value shown in Fig. 15, the evaporation from the sea is estimated to be $6 \mathrm{~mm} \cdot$ day $^{-1}$.

It must be emphasized, at the end of this section, that there is a strong northward vapor flux across the southern boundary of the front, which contributes to both the longitudinal flux divergence and the net convergence inside the front.

* In the present case, we treat the water vapor budget in an air column from surface to 500$\mathrm{mb}$. This has been, however, proved to represent approximately the vapor amount in the whole troposphere throughout, because the vapor amount to $400-\mathrm{mb}$ estimated in area $\mathrm{C}$ deviates only slightly from the one to $500-\mathrm{mb}$. 


\section{Intensification of the Baiu Front along the northwestern rim of the Northern Pacific Subtropical anticyclone}

In previous sections, we analyzed the large-scale synoptic aspects of the Baiu Front throughout this season. One of the results obtained is that there is a significant difference between the frontal activities in the vicinity of the western Japan Islands and that over the inner continent. For instance, intense precipitation, the maximum cloudiness, the strongest low-level wind, etc., are found over the former area. These seem to indicate more intense frontal activities over western Japan than over the continent. Now, we will discuss the role of the Northern Pacific Subtropical anticyclone covering the western Pacific ocean in intensifying the Baiu Front.

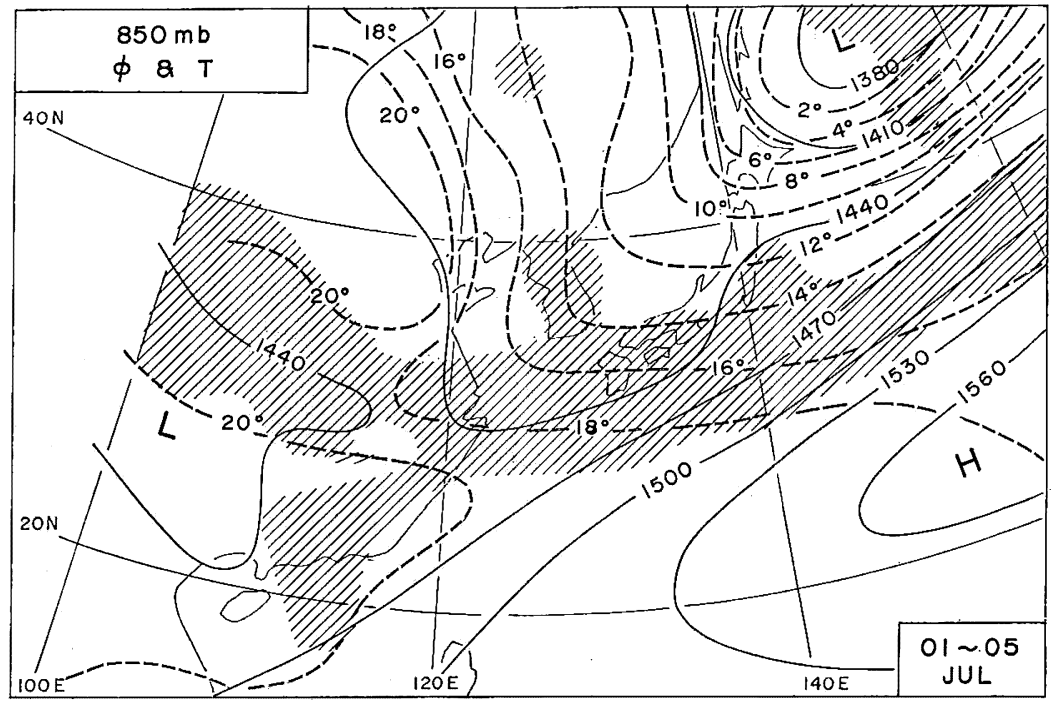

Fig. 16. Mean 850-mb chart during the period from July 1 to July 5, 1968. Hatched area shows the heavy cloud zone.

In Fig. 16 are shown the mean $850-\mathrm{mb}$ surface map and the maximum cloudiness area (hatched area) corresponding to the Baiu Front for the 5-day period from July 1 to July 5, 1968. It is clearly seen that there is a vast subtropical anticyclone zone to the south of the front over the ocean. Although the 850-mb thermal gradient in the cloud zone is not so concentrated as that of the polar front in the winter season, yet there is a moderate gradient of geopotential height and temperature along the northwestern rim of the anticyclone. As one of the influences of this, it is supposed, the geostrophic strong low-level wind there contributes to increasing the water vapor flow along the frontal area. Moreover, it is generally said that such a confluent current superimposed on the zone of concentrated thermal gradient results in frontogenesis or intensification of the front (PETTERsEN, 1956). As seen in Fig. 16, confluence of geostrophic wind to the south coastal region of Japan will result in intensification of frontal activities through the process mentioned above. The convective motion within the frontal zone thus intensified increases the ageostrophic low-level wind through the work of convective mixing of momentum as discussed in the previous section. This ageostrophic low-level wind induces vertical circulation which, in turn, causes severe rainfalls. 


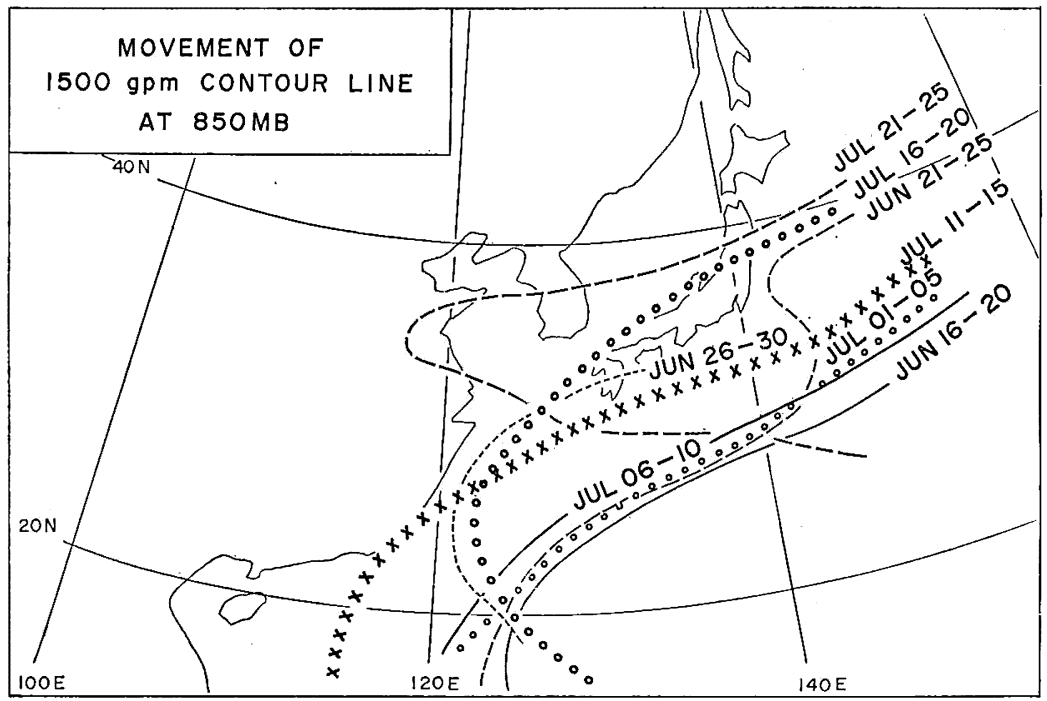

Fig. 17. Movement of contour lines of $1500 \mathrm{gpm}$ at the $850-\mathrm{mb}$ surface during the period from June 16 to July 25, 1968.

Now, we will examine the movements of the subtropical high and its influence upon the Baiu Front for the analyzed periods. In Fig. 17 are shown 1500 gpm contours at the $850-\mathrm{mb}$ surface, which indicate roughly the outline of the Northern Pacific subtropical anticyclone. The high pressure zone shifts northwards gradually in the Baiu season, rapidly in its last stage. Here, we notice a significant change in frontal activities in the middle of July. During the period from June 16 to July 15, the Baiu Front is intensified along the northwestern rim of the high pressure region. On the other hand, during the 5-day period from July 21 to July 25 the frontal activities are remarkably weakened. In other words, after this season the belt-shaped maximum cloudiness zone disappears, and either water vapor flux or low-level wind speed decreases also. At this time the Northern Pacific Subtropical anticyclone elongates towards the middle latitudinal continental anticyclone and a huge high pressure belt is formed over the Far East. It is considered that owing to the huge high pressure belt, vapor flow into the frontal zone from the tropical oceanic region is restrained and at the same time the frontal activities decay.

\section{Summary}

The large-scale aspects of the Baiu Front and associated phenomena over the Far East were analyzed for the 40-day period from June 16 to July 25, 1968, mainly by using 5 -day mean fields. The main purpose of the study is to clarify the physical relations among the ageostrophic low-level jet stream, moist tongue, convective warming, convergence zone and heavy rainfalls.

The results are summarized as follows:

1) The Baiu Front, in its large-scale aspects, is a belt-shaped zone of maximum cloudiness extending along the northern boundary of the monsoon and/or tropical airmass. 
2) This cloudy zone coincides with the heavy rainfall area and is also a zone of persistent convective activities. A fairly large value of low-level convergence is inferred from observed precipitation. In view of this, the Baiu Front may be called a large-scale convergence zone.

3) A deep moist layer, i.e., so-called "moist tongue", is found over the Baiu Front. The quantitative analysis of the moisture field indicates that the moist tongue is not caused by horizontal moisture advection, but convective vertical transport of moisture in the convergence zone.

4) The mean low-level jet appears along the south side of the front. The low-level jet is especially strong over the heavy rain area, and is characterized by a remarkable ageostrophic component. These features of the low-level jet suggest that its formation is due to convective momentum mixing rather than the topographic influence of the Japan Islands.

5) Medium-scale cyclones with wavelengths of about $1,000 \mathrm{~km}$ develop to the north of the low-level jet stream. Since both vertical and horizontal shears within the lower troposphere of the northern part of the Baiu Front are strong and the stratification there is nearly neutral, favorable conditions for the generation of mediumscale disturbances are provided there.

6) Mid-upper tropospheric warming in the cloudy zone indicates the influence of convective warming. The local intensification of the upper jet to the north of a heavy rainfall area is considered to be caused by the increasing of the thermal gradient to the north of the warming area through the relation given by the thermal wind equation.

7) The result of water vapor budget analysis indicates that water vapor convergence into the frontal zone is accomplished mainly by northward inflow in the lower layer. 8) The evaporation from the South China Sea and the western Pacific Ocean is one of the water vapor sources which maintain the moist northward flow into the frontal zone.

9) The Baiu Front is especially intensified in the vicinity of the western Japan Islands to the northwest of the Northern Pacific Subtropical anticyclone througout the Baiu season. The strong southerly geostrophic wind along the northwestern rim of the anticyclone transports water vapor into the frontal zone. The large-scale geostrophic confluence there also causes large-scale frontogenesis. The generation of convective motion in the Baiu Front thus intensified through large-scale processes results in the increasing of the low-level wind velocity through convective momentum mixing. The ageostrophic component of the increasing low-level wind induces vertical upward motion which further produces heavy rainfall. By the process mentioned above, a very active Baiu Front is formed over the Japan Islands. Medium-scale disturbances develop in the frontal zone where moist and neutral stratification is provided by convective mixing.

Aknowledgements-The author wishes to express her hearty thanks to Dr. K. Ninomiya, Meteorological Research Institute, for his stimulative guidance throughout the study. She is also greatly indebted to the members of the Severe Rainstorms Research Project for various forms of support. 


\section{References}

AsAKuRA, T., 1971a: Transport and source of water vapor in the northern hemisphere and monsoon Asia. Water Balance of Monsoon Asia, Univ. Tokyo Press. pp 308, 27-51.

, 1971b: Distribution and variation of cloudiness and precipitable water during the rainy season over monsoon Asia. Water Balance of Monsoon Asia. Univ. Tokyo Press, pp 308, 131-151.

Findlater, J., 1969: A major low-level air current near the Indian Ocean during the northern summer. Quart. J. R. Met. Soc., 95, 362-380.

GAMBo, K., 1970a: The characteristic feature of medium-scale disturbances in the atmoshere (I). J. Met. Soc. Japan, 48, 173-184.

,1970b: The characteristic feature of medium-scale disturbances in the atmosphere (II). J. Met. Soc. Japan, 48, 315-330.

Haltiner, G. J., 1971: Numerical weather prediction. John Wiley and Sons Inc., pp. 161-166.

HoEckeR, W. H., Jr., 1963: Three southerly low-level jet systems delineated by the weather Bureau special pibal network of 1961. Mon. Wea. Rev., 91, 573-582.

Kurashima, A., 1968: Studies on the winter and summer monsoons in East Asia based on dynamic concept. Geophys. Mag., 34, 145-235.

MANABE, S., 1956: On the contribution of heat released by condensation to the change in pressure pattern. J. Met. Soc. Japan, 34, 308-320.

Matsumoto, S., 1972: Unbalanced low-level jet and solenoidal circulation associated with heavy rainfalls. J. Met. Soc. Japan, 50, 194-203.

Matsumoto, S. and K. Ninomiya, 1971: On the mesoscale and medium-scale structure of a cold front and the relevant vertical circulation. J. Met. Soc. Japan, 49, Special Issue. 648-662.

Matsumoto, S., K. NinomiYA and S. Yoshizumi, 1971: Characteristic features of "Baiu" front associated with heavy rainfall. J. Met. Soc. Japan, 49, 267-281.

Matsumoto, S., S. Yoshizumi and M. TAKeuchi, 1970 : On the structure of the "Baiu front" and the associated intermediate-scale disturbances in the lower atmosphere. J. Met. Soc. Japan, 48, 479-491.

MurakAmI, T., 1959: The general circulation and water-vapor balance over the Far East during the rainy season. Geophys. Mag., 29, 131-171.

NinomiYA, K., 1971a: Dynamical analysis of outflow from tornado-producing thunderstorms as revealed by ATS III pictures. J. Applied Met., 10, 275-294.

, 1971b: Mesoscale modification of synoptic situations from thunderstorm development as revealed by ATS III and aerological data. J. Applied Met., 10, 1103-1121.

NinomiYA, K. and T. AKryama, 1971: The development of the medium-scale disturbance in the Baiu Front. J. Met. Soc. Japan, 49, Special Issue, 663-677.

, 1972: Medium-scale echo clusters in the Baiu front as revealed by multi-radar composite echo maps. (Part 1), J. Met. Soc. Japan, 50, 558-569.

OTANI, T., 1954 : Converging line of the northeast trade wind and converging belt of the tropical air current. Geophy. Mag., 25, 1-122.

Petterssen, S., 1956: Weather analysis and forecasting. McGRAW-HILL INC., New York, pp. 189-213.

RAMAge, C.S., 1971 : Monsoon meteorology. Academic Press, pp. 296.

RAO, G. and A. HASsEbrock, 1972: Mesoscale latent heat release and its influence on mid-tropospheric warming. J. Applied Met, 11, 1271-1283.

Sarto, N., 1966: A Preliminary study the summer monsoon of southern and eastern Asia. J. Met. Soc. Japan, 44, 44-59.

TokıokA, T., 1970: Non-geostrophic and non-hydrostatic stability of a baroclinic fluid. J. Met. Soc. Japan, 48, 503-520.

WEXLER, H., 1961: A boundary layer interpretation of the low-level jet. Tellus, 13, 368-378.

Yoshino, M. M., 1966 : Four stages of the rainy season in early summer over East Asia (Part II). J. Met. Soc. Japan, 44, 209-217. 


\section{広域からみた梅雨前線帯の特徵}

一一特に，前線内の非地衡風的な下層 jet，湿舌，対流昇温，収束帯牤よび

豪雨との関連に重点を於いて—

秋山孝子

梅雨前線特よびこれに関連する現象については，すでにいくつかの解析がある。それらは大別して2つの 系統の研究にわけられる。一つは, 村上 (1959), 吉野 (1966), 朝倉 (1971，a，b), 斉藤 (1966) らに代 表される，マクロなあるいは，気候学的な立場からなされたものであり，他の一つは，松本ら $(1970,1971)$ に代表されるような，総観規模ないしは，中間規模的な観点に立つ研究である。

後者の研究は豪雨時の豪雨域に和ける梅雨前線の特徵——下層 jet, 中間規模じょう乱, moist-warming tongue一一などの詳細を明らかにしているが，梅雨期全体，あるいは広い極東域における梅雨前線全体につ いて，言及しているわけではない。

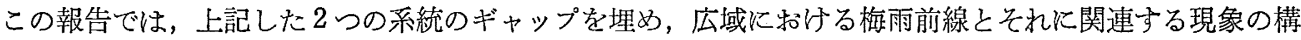
造と振舞をより明確にすることを目的としている。

すなわち，1968年 6 月16日から 7 月 25 日にいたる40日間について，極東域の梅雨前線帯の特徵を，主とし

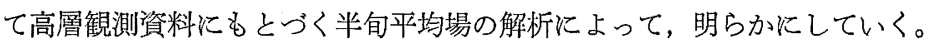

得られた主要な結果は下記の如く要約される。

1）広域からみた梅雨前線帯は, 熱帯性気団の北限境界付近に横たわる顕著な帯状の雲量極大域として認め られる。その帯状の雲域は，季節の進行とともに徐々に北上する。

2）また帯状の雲域は降雨帯とも一致し，特に平均雲量 4 以上の雲域は活湾 $50 \mathrm{~mm} / 5$ day の雨域と一致す る。降雨の量っよび状況は, 持続した積雲対流活動の存在を示しており, 帯状の雲域の対流層内には, 厚い 湿潤層が見出される。

3）平均場の下層 jet 軸は，大きな非地衡風成分を持ち，降雨域に付随しているのが認められる。このこと は, 梅雨前線内の下層 jet が, 単に地形効果によって生成されるものでないことを示するのである。下層ジ エットの特徴的なプロフフイルは下層 jet の生成に, 降雨域に抢ける対流活動による水平運動量の下向き輸 送が寄与していることを示唆している。

4）下層ジェットの北側の前線帯内は，垂直・水平シャーとも強く，成層は注ぼ中立であって，中間規㷬じ ょう乱の発生し易い領域であることが示される。

5）前線帯の上層には，対流活動による潜熱の放出掞よび，顕熱の上向き輸送の 結果と思われる温暖層が あり，それによって前線带北縁の上層風が強化されている。

6）前線带の水蒸気収支を調べた結果，前線帯への水蒸気の収束は，主として，下層における高湿気流の前 線帯南側境界からの流入によることが分る。この高湿気流のオリジンとして重要な前線帯南方洋上の湿潤気 団の形成は，海面からの蒸発によるものである。

7）以上のべたような梅雨前線の特徴が最も顕著にみられるのは日本列島近傍に执いてである。この領域は

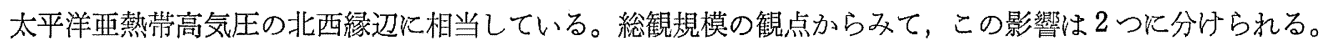
高気圧の北西縁辺をなる南西風が，単に地衡風的に強く，水蒸気の前線への流入を增加させるだけでな く，風の合流の場が大規模な垂直循環をひき抗していると思われる。このように大規模的に強化された前 線帯に拄いて，持続する対流活動の結果，前述した下層ジェットが形成され，その中心付近ではさらに降水 活動が強化される。形成された厚い湿潤層のなかでは，中間規模じょう乱が発達する。

以上の過程によって，われわれが実際に観察するような，特徵的梅雨前線帯が日本列島上に形成される。 本報告は, 気象研究所, 梅雨未期集中豪雨特別研究の一部としてなされたものである。 